\title{
Phenyldihydropyrazolones as Novel Lead Compounds Against Trypanosoma cruzi
}

Maarten Sijm, ${ }^{\dagger}$ Julianna Siciliano de Araújo, ${ }^{\ddagger}$ Stefan Kunz, ${ }^{\dagger}$ Susanne Schroeder, ${ }^{\S}$ Ewald Edink, ${ }^{\dagger}$ Kristina M. Orrling, ${ }^{\dagger}$ An Matheeussen, ${ }^{\|}$Tiffany van de Meer, ${ }^{\dagger}$ Payman Sadek, ${ }^{\dagger}$ Hans Custers, ${ }^{\dagger}$ Ignacio Cotillo, ${ }^{\perp}$ Julio J. Martin, ${ }^{\perp}$ Marco Siderius, ${ }^{\dagger}$ Louis Maes,,${ }^{\|}$David G. Brown, ${ }^{\S}$ Maria de Nazaré Correia Soeiro, ${ }^{\ddagger}$ GeertJan Sterk, ${ }^{\dagger}$ Iwan J.P. de Esch, ${ }^{\dagger}$ and Rob Leurs ${ }^{*}{ }^{\dagger} \odot$

${ }^{\dagger}$ Division of Medicinal Chemistry, Faculty of Sciences, Amsterdam Institute for Molecules, Medicines and Systems (AIMMS), Vrije Universiteit Amsterdam, De Boelelaan 1108, $1081 \mathrm{HZ}$ Amsterdam, The Netherlands

${ }^{\ddagger}$ Laboratório de Biologia Celular, Oswaldo Cruz Institute (Fiocruz), Av. Brasil, 4365-Manguinhos, RJ, $21040-900$ Rio de Janeiro, Brazil

${ }^{\S}$ School of Biosciences, University of Kent, Canterbury CT2 7NJ, U.K.

"Laboratory for Microbiology, Parasitology and Hygiene (LMPH), University of Antwerp, Universiteitsplein 1, 2610 Antwerpen, Belgium

${ }^{\perp}$ Diseases of the Developing World, GlaxoSmithKline, Calle de Severo Ochoa, 2, 28760 Tres Cantos, Madrid, Spain

Supporting Information

ABSTRACT: As over 6 million people are infected with Chagas disease and only limited therapeutic options are available, there is an urgent need for novel drugs. The involvement of cyclic nucleotide phosphodiesterases (PDE) in the lifecycle and biological fitness of a number of protozoan parasites has been described and several of these enzymes are thought to be viable drug targets. Within this context, a PDE-focused library was screened for its ability to affect the viability of Trypanosoma cruzi parasites. 5-(3-(Benzyloxy)-4methoxyphenyl)-2-isopropyl-4,4-dimethyl-2,4-dihydro-3H-pyrazol-3-one (4), previously reported as a human PDE4 inhibitor, was identified as a hit. Upon optimization on three positions of the phenylpyrazolone scaffold, 2-isopropyl5-(4-methoxy-3-(pyridin-3-yl)phenyl)-4,4-dimethyl-2,4-dihydro-3H-pyrazol3 -one (34) proved to be the most active compound against intracellular forms of T. cruzi $\left(\mathrm{pIC}_{50}=6.4\right)$ with a 100 -fold selectivity with respect to toxicity toward human MRC-5 cells. Evaluation on different life stages and clinically relevant T. cruzi strains revealed that the phenylpyrazolones are not active against the bloodstream form of the $\mathrm{Y}$ strain but show submicromolar activity against the intracellular form of the $\mathrm{Y}$ - and Tulahuen strains as well as against the nitro-drug-resistant Colombiana strain. In vitro screening of phenylpyrazolones against TcrPDEB1, TcrPDEC, and TcrCYP51 showed that there was a poor correlation between enzyme inhibition and the observed phenotypic effect. Among the most potent compounds, both TcrCYP51 and non-TcrCYP51 inhibitors are identified, which were both equally able to inhibit T. cruzi in vitro.

\section{INTRODUCTION}

Trypanosoma cruzi, a protozoan parasite, is the causative agent of Chagas disease. ${ }^{1}$ This disease was once only endemic in Latin-America, however as human mobility increases it is now spreading into other areas such as Europe, Australia, NorthernAmerica, and Middle America. ${ }^{2-5}$ It is estimated that approximately 6 million people are currently infected worldwide. $^{6}$ Of all individuals carrying this infection about $30 \%$ will develop a progressive chronic cardiomyopathy and another $10 \%$ will develop digestive, neurological, or mixed clinical symptoms.

While the current drugs benznidazole (Radanil) (1, Figure 1) and nifurtimox (Lampit) (2) are quite effective in curing the disease in its initial acute phase, efficacy of these drugs during the chronic disease phase is much less evident. ${ }^{8}$ The recent BENEFIT trial on the efficacy of benznidazole (1) in patients with chronic Chagas disease reported that the cardiac deterioration was not significantly impaired, despite the significantly reduced serum parasitemia.9 Moreover, besides their limited efficacy in the chronic phase, both benznidazole (1) and nifurtimox (2) exhibit severe side effects, require long drug administration, and are ineffective against naturally resistant T. cruzi strains. ${ }^{10,11}$ Despite these risks and limitations and its relatively high disease burden, the drug discovery

Received: October 31, 2018

Accepted: April 1, 2019

Published: April 10, 2019 

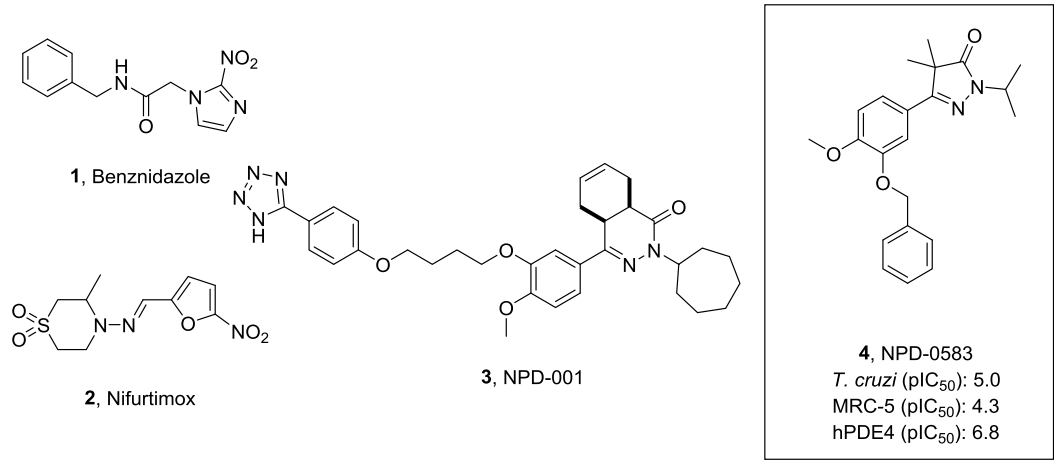

Figure 1. Current drugs against T. cruzi: benznidazole (1), nifurtimox (2), PDE inhibitor NPD-001 (3), which is able to kill T. brucei, and phenyldihydropyrazolone NPD-0583 (4) hit from the phenotypic screening.

pipeline for Chagas disease does not provide high hopes for a novel treatment on a short term notice. ${ }^{12}$

Mainly academic groups have been trying to fill this innovation gap, although there are some collaborations with industry in public-private partnerships. ${ }^{13-15}$ In this paper, we describe part of the research of the EU-funded, public-private consortium PDE4NPD (www.PDE4NPD.eu), that focuses on $3^{\prime} 5^{\prime}$-cyclic nucleotide phosphodiesterases (PDEs) as targets against a number of neglected tropical diseases. PDEs are enzymes that hydrolyze phosphodiesterase bonds such as those found in the intracellular (IC) cyclic nucleotides cAMP and cGMP and thereby are involved in the control of IC signalling. ${ }^{16}$ Level control of the secondary messengers cAMP and cGMP is essential in various cell functions, for example differentiation, proliferation, and regulation of osmotic stress in a variety of cells, including parasites. ${ }^{17-19}$ In kinetoplastida, four different PDE families have been identified, namely PDEA-PDED, which show high homology between the different kinetoplastid species. ${ }^{20}$

Previously, the effectiveness of targeting parasite PDEs has been shown for Giardia lamblia and the closely related protozoan parasite Trypanosoma brucei. ${ }^{21-23}$ An inhibitor of two parasite PDEs TbrPDEB1 and TbrPDEB2, NPD-001 (3, Figure 1; also disclosed as a human PDE4 inhibitor), elevated IC cAMP levels, disrupted regulation of the cell cycle, and ultimately lead to death of the trypanosomes. ${ }^{24,25}$ Moreover, the importance of PDEs in controlling cAMP levels and thereby regulating cellular processes such as regulatory volume control in T. cruzi has been reported. ${ }^{26-28}$ One of the PDE family members, TcrPDEC, has subsequently been suggested as an antiparasitic drug target. ${ }^{29}$

As PDE inhibition seems a viable approach toward new treatments against kinetoplastids, an in-house library of known PDE inhibitors was screened against $T$. cruzi in phenotypic assays. In this screening effort, the human PDE4 inhibitor $\left(\right.$ hPDE4 pIC $\left._{50}=6.8\right)$ NPD-0583 (4, Figure 1), previously also reported by Orrling et al. as TbrPDEB1 inhibitor $\left(\mathrm{pIC}_{50}=\right.$ 5.4), was identified as a hit against the IC form of T. cruzi $\left(\mathrm{pIC}_{50}=5.0\right) .^{21}$ On the basis of these results, three positions of the core scaffold were selected for optimization: the benzyloxy moiety $R_{1}$, the pyrazolone nitrogen substituent $R_{2}$, and the methoxy moiety on $\mathrm{R}_{3}(\mathbf{5}$, Figure 2$)$.

\section{CHEMISTRY}

For hit optimization and SAR analysis, we designed a synthetic route that allowed efficient modification at all three positions. Orrling et al. ${ }^{21}$ reported a similar route for this chemical class;<smiles>COc1ccc(C2=NN(C(C)C)C(=O)C2(C)C)cc1OCc1ccccc1</smiles><smiles>[R3]Oc1ccc(C2=NN([R])C(=O)C2(C)C)cc1[R1]</smiles>

Figure 2. Hit molecule NPD-0583 (4) from which the phenylpyrazolone scaffold $\mathbf{5}$ was derived for further SAR (structure-activity relationship) exploration.

however, some small modifications were made to the first three steps.

In the first step, the acid chloride of benzoic acid 6 was formed and subsequently condensed with the separately formed lithium enolate of methylisobutyrate (Scheme 1). The resulting $\beta$-keto-ester 7 was used crude for the ring closure with hydrazine to give key intermediate 8 in $89 \%$ yield over two steps. With dihydropyrazolone $\mathbf{8}$ at hand, the first substituent of choice could be introduced on the pyrazolone nitrogen $\left(\mathrm{R}_{2}\right)$ via an alkylation with the desired aliphatic bromine. These $\mathrm{N}$-alkylated intermediates (9-21, Scheme 1) were used in either a Suzuki reaction to install the final aryl substituent $\left(\mathrm{R}_{1}\right)(\mathbf{2 2 - 4 7 , 5 1 - 6 4}$, Scheme 1$)$ or in a Buchwald reaction to install aliphatic amines $(48-50)$. The third and final position $\left(\mathrm{R}_{3}\right)$ could be modified after demethylation of intermediate 11 (5-(3-bromo-4-methoxyphenyl)-2-isopropyl4,4-dimethyl-2,4-dihydro-3H-pyrazol-3-one), followed by subsequent $\mathrm{O}$-alkylation. The newly obtained $\mathrm{O}$-alkyl intermediates (66-74, Scheme 1) were used in a Suzuki reaction to install the final aryl substituent $\left(\mathrm{R}_{1}\right),(\mathbf{7 5}-83)$.

\section{PHARMACOLOGY AND PARASITOLOGY}

All compounds were initially tested for their trypanocidal activity against IC forms of $T$. cruzi, Tulahuen CL2, $\beta$ galactosidase strain (drug sensitive strain, (discrete typing units, DTU VI)) as well as for cytotoxicity on MRC- $5_{\mathrm{SV} 2}$ cells (human lung fibroblasts). In-depth pharmacological profiling was performed using IC amastigotes from the naturally highly and moderately nitro-drug-resistant Colombiana strain (DTU I) and from the Y-strain (DTU II), respectively. Additionally, bloodstream trypomastigotes (BT) of the Y-strain obtained from infected Swiss Webster mice were used. Toxicity profiling was done using primary cell cultures of mouse embryonic cardiac cells. TcrCYP51 inhibition assays were performed 
Scheme $1^{a}$
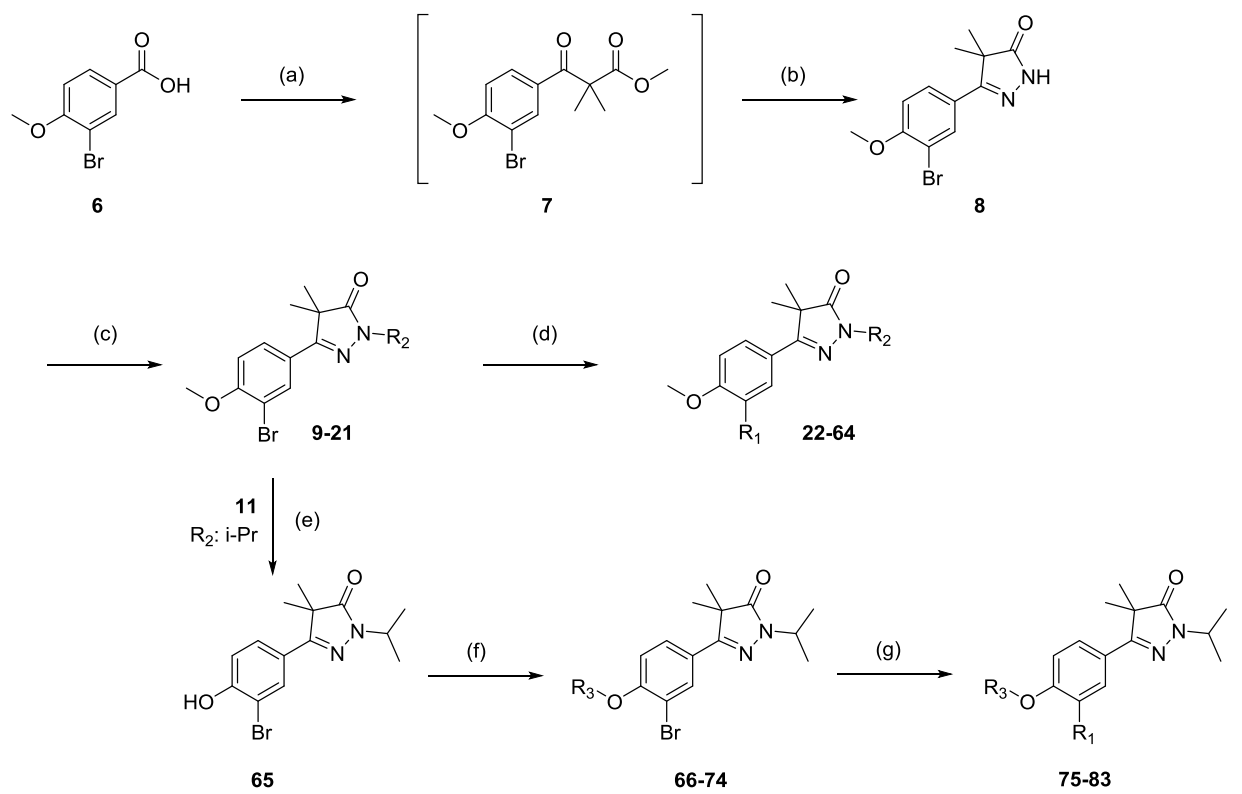

${ }^{a}$ Reagents and Conditions: (a) (i): $\left(\mathrm{COCl}_{2}\right)$, DMF, DCM, $2 \mathrm{~h}$, rt, (ii): methylisobutyrate, LDA, THF, $-78{ }^{\circ} \mathrm{C}$ to rt; $(\mathrm{b}) \mathrm{N}_{2} \mathrm{H}_{4} \cdot \mathrm{H}_{2} \mathrm{O}, \mathrm{EtOH}, 18 \mathrm{~h}$, rt; 89\% Over Two Steps; (c) NaH, $\mathrm{R}_{2}-\mathrm{Br}$, DMF, $2 \mathrm{~h}, 50{ }^{\circ} \mathrm{C}$; 70-95\%; (d) $\mathrm{R}_{1}-\mathrm{B}\left(\mathrm{OH}_{2}\right), \mathrm{Pd}(\mathrm{dppf}) \mathrm{Cl}_{2} \cdot \mathrm{CH}_{2} \mathrm{Cl}_{2}, 1 \mathrm{M} \mathrm{Na}_{2} \mathrm{CO}_{3}, \mathrm{DME}, 1 \mathrm{~h}, 120{ }^{\circ} \mathrm{C} \mu \mathrm{W}$; 14-94\%; (e) 11, $\mathrm{BBr}_{3}$, DCM, 18 h, rt; 90\%; (f) R $-\mathrm{Br}$, DMF, $3 \mathrm{~h}, 50{ }^{\circ} \mathrm{C}$; 17-96\%; (g) R $-\mathrm{B}\left(\mathrm{OH}_{2}\right), \mathrm{Pd}(\mathrm{dppf}) \mathrm{Cl}_{2} \cdot \mathrm{CH}_{2} \mathrm{Cl}_{2}, 1 \mathrm{M} \mathrm{Na}_{2} \mathrm{CO}_{3}, \mathrm{DME}, 1 \mathrm{~h}$, $120{ }^{\circ} \mathrm{C} \mu \mathrm{W} ; 30-94 \%$

using CYP51 (full length) from the Tulahuen strain using the fluorescence based assay reported by Riley et al. ${ }^{30}$ The catalytic domains of Tcr(Y)PDEC (aa 270-614) and Tcr(Y)PDEB1 (aa 564-918) were amplified by PCR from full length sequences and cloned (NdeI and XhoI) into the vector pET28a. ${ }^{31}$ Protein production and purification of both Tcr(Y)PDE_CDs were performed following the same protocol. Escherichia coli strain BL21(DE3)*pLysS was transformed with either plasmid pET28aTcr(Y)PDEC_270-614 or pET28aTcr(Y)PDEB1_564-918 and the resulting recombinant strains were grown in $2 \mathrm{YT}$ medium at $37{ }^{\circ} \mathrm{C}$. A typical purification yielded about $10 \mathrm{mg}$ Tcr(Y)PDEC_CD and $7 \mathrm{mg}$ Tcr(Y)PDEB1_CD from a $1 \mathrm{~L}$ cell culture. PDE activity assays are performed using the PDELight HTS cAMP phosphodiesterase kit (Lonza, Walkersville, USA).

\section{RESULTS AND DISCUSSION}

Compounds from an in-house PDE-focused library were screened in vitro for their trypanocidal effect against the IC form of T. cruzi (Tulahuen CL2 strain transfected with $\beta$ galactosidase gene) and their toxicity on human lung fibroblasts (MRC-5). NPD-0583 (4) was identified as a "hit" from which the phenyl-pyrazolone scaffold (5, Figure 2) was derived for further optimization. As the catechol moiety of NPD-0583 (4) is a chemotype commonly observed in human PDE4 inhibitors, and human PDE off-target activity is preferably avoided, the first analogues synthesized did not contain the 3-benzyloxy moiety. Instead, the phenyl group was attached directly to the pyrazolone-phenyl scaffold, leading to compound 22 (Table 1), which has a similar activity as NPD0583 (4) with a $\mathrm{pIC}_{50}$ of 5.1. Moreover, substituted phenyl analogues (23-32, Table 1) showed a similar or improved activity over NPD-0583 (4, Figure 1). While introduction of a 2 -fluorophenyl (23) led to diminished activity $\left(\mathrm{pIC}_{50}<4.2\right)$, both the 3- and 4-fluorophenyl analogues (24-25, Table 1) showed a substantial increase in activity over the unsubstituted phenyl (22) with $\mathrm{pIC}_{50}$ values around 6. Introduction of a 3and 4-chloro- or methoxyphenyl ring (26-29, Table 1) also increased activity compared to the unsubstituted phenyl analogue (22) with $\mathrm{pIC}_{50}$ values around 5.5. The most active substituted phenyl derivative was the 3-cyanophenyl-substituted compound (30) with a $\mathrm{pIC}_{50}$ of 6.4 , while the 4cyanophenyl analogue (31, Table 1) had an activity of 5.6. Substituting both the 3- and 4-position, as seen with dimethoxyphenyl 32 did not improve activity $\left(\mathrm{pIC}_{50}=4.9\right.$, Table 1).

Introduction of pyridines on the $\mathrm{R}_{1}$ position led to mixed results. The 2-pyridine analogue 33 (Table 1) showed almost no activity, while the 3- and 4-pyridine substituted phenyldihydropyrazolones (34-35) were amongst the most potent analogues with $\mathrm{pIC}_{50}$ values of 6.4 and 5.8, respectively. Introduction of a fluorine on the 4-position of the 3-pyridine (36) did not affect the activity, while substitution with larger substituents such as 4-methyl (37), 4-methoxy (38), and 4cyano (39) resulted in a 10-fold decrease in potency (Table 1 ). Introduction of a methyl group on the 6-position of the 3pyridinyl moiety (40) decreased activity even further. Adding a small substituent on the 3-position of 4-pyridines resulted in a significant increase in activity; the 3-fluoro-4-pyridinyl analogue (41, Table 1) is for example very active with a $\mathrm{pIC}_{50}$ of 6.3, while the 3-methyl-4-pyridinyl (42) analogue has a $\mathrm{pIC}_{50}$ of 6.4 , as opposed to 5.8 for the unsubstituted 4pyridinyl (35). These activities are similar to 3-pyridinylphenylpyrazolone $34\left(\mathrm{pIC}_{50}=6.4\right)$, the most potent compound in the series obtained so far. Introduction of other heterocycles such as a pyrimidine (43, Table 1$)$, indole (44), isoquinoline (45), furan (46), and thiophene (47) generally caused a large decrease in activity, exception being pyrimidine $\mathbf{4 3}$ which only showed a minor decrease in activity $\left(\mathrm{pIC}_{50}=6.0\right)$ compared to the 3-pyridine substituted phenylpyrazolone 34 . 
Table 1. Phenotypic Activity against IC Amastigotes of T. cruzi (Tulahuen Strain) and on MRC-5 Cell Growth by Phenyldihydropyrazolones with Modification on the $R_{1}$ Position

(1)

${ }^{a}$ All reported values are within a standard deviation of \pm 0.2 .

Table 2. Phenotypic Activity against IC Amastigotes of T. cruzi (Tulahuen Strain) and on MRC-5 Cell Growth by Phenyldihydropyrazolones with Modification on the $\mathbf{R}_{2}$ Position

\begin{tabular}{|c|c|c|c|c|c|c|c|}
\hline Compd & $\mathrm{R}_{2}$ & $\begin{array}{c}T . c r \\
\left(\mathrm{pIC}_{50}\right)^{\mathrm{a}} \\
\end{array}$ & $\begin{array}{l}\text { MRC-5 } \\
(\mathrm{pIC} 50)^{\mathrm{a}}\end{array}$ & Compd & $\mathrm{R}_{2}$ & $\begin{array}{c}T . c r \\
\left(\mathrm{pIC} \mathrm{C}_{50}\right)^{\mathrm{a}}\end{array}$ & $\begin{array}{l}\text { MRC-5 } \\
\left(\mathrm{pIC}_{50}\right)^{\mathrm{a}}\end{array}$ \\
\hline 51 & $\mathrm{H}^{-}$ & 4.4 & $<4.2$ & 58 & & 5.7 & 4.9 \\
\hline 52 & $\mathrm{Me}^{--}$ & 4.6 & $<4.2$ & 59 & & 4.3 & $<4.2$ \\
\hline 53 & & 5.4 & $<4.2$ & 60 & & 5.4 & $<4.2$ \\
\hline $\begin{array}{c}\mathbf{3 4} \\
\text { (NPD- } \\
0227 \text { ) }\end{array}$ & & 6.4 & 4.4 & 61 & & 5.9 & $<4.2$ \\
\hline 54 & & 6.2 & 4.6 & 62 & & 5.0 & $<4.2$ \\
\hline 55 & & 6.4 & 4.6 & 63 & & 5.3 & $<4.2$ \\
\hline 56 & & 6.0 & 4.5 & 64 & & 5.8 & $<4.2$ \\
\hline 57 & & 6.5 & 4.7 & & & & \\
\hline
\end{tabular}

${ }^{a}$ All reported values are within a standard deviation of \pm 0.2 . 
Table 3. Phenotypic Activity against IC Amastigotes of T. cruzi (Tulahuen Strain) and on MRC-5 Cell Growth by Phenyldihydropyrazolones with Modification on the $R_{3}$ Position

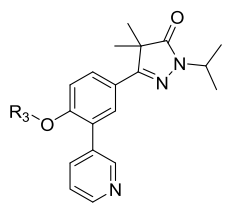

\begin{tabular}{|c|c|c|c|}
\hline Compd & $\mathrm{R}_{3}$ & $\begin{array}{c}T . c r \\
\left(\mathrm{pIC}_{50}\right)^{\mathrm{a}}\end{array}$ & $\begin{array}{l}\text { MRC-5 } \\
\left(\mathrm{pIC}_{50}\right)^{\mathrm{a}}\end{array}$ \\
\hline $\begin{array}{c}\mathbf{3 4} \\
\text { (NPD- } \\
0227 \text { ) }\end{array}$ & $\mathrm{Me}^{--}$ & 6.4 & 4.4 \\
\hline 75 & & 5.0 & 4.5 \\
\hline 76 & & 5.1 & 4.6 \\
\hline 77 & & 6.0 & 4.6 \\
\hline 78 & & 6.1 & 5.2 \\
\hline
\end{tabular}

\begin{tabular}{|c|c|c|c|}
\hline Compd & $\mathrm{R}_{3}$ & $\begin{array}{c}T . c r \\
\left(\mathrm{pIC}_{50}\right)^{\mathrm{a}}\end{array}$ & $\begin{array}{l}\text { MRC-5 } \\
\left(\mathrm{pIC}_{50}\right)^{\mathrm{a}}\end{array}$ \\
\hline 79 & & 5.6 & $<4.2$ \\
\hline 80 & & 5.1 & 4.7 \\
\hline 81 & & 5.0 & $<4.2$ \\
\hline 82 & & 4.4 & $<4.2$ \\
\hline 83 & & 4.9 & 4.4 \\
\hline
\end{tabular}

${ }^{a}$ All reported values are within a standard deviation of \pm 0.2 .

To extend the SAR on this position, several non-aromatic heterocycles $(\mathbf{4 8 - 5 0}$, Table 1$)$ were introduced on the $\mathrm{R}_{1}$ position, but the activity was 100 -fold lower than the most potent hits obtained so far, showing that an aromatic feature is preferred on this position.

In the obtained set of phenyldihydropyrazolones with different $\mathrm{R}_{1}$ substituents, several compounds show potencies around $6.4\left(\mathrm{pIC}_{50}\right)$. Since 3-pyridinyl 34 (NPD-0227) has the lowest $\operatorname{cog} P$, low MRC-5 toxicity, and does not contain a fluorine moiety that has the potential risk of nucleophilic aromatic substitution, SAR exploration on the $R_{2}$ and $R_{3}$ position (5, Figure 2) was further done using this moiety on the $\mathrm{R}_{1}$ position. Initially, the $N$-unsubstituted phenyldihydropyrazolone (51) as well as different sizes of branched and unbranched aliphatic chains (52-58, Table 2) were synthesized and evaluated on the $\mathrm{R}_{2}$ position. While the nonsubstituted compound (51, Table 2) is virtually inactive with an $\mathrm{pIC}_{50}$ of 4.4 , adding aliphatic $\mathrm{R}_{2}$ substituents substantially increased activity. While introduction of a methyl group (52, Table 2) resulted only in a minor increase, the $N$-ethyl substituted dihydropyrazolone (53) showed a 10-fold increase in parasitic activity $\left(\mathrm{pIC}_{50}=5.4\right)$. This activity was further increased by adding another methyl moiety, as in the $\mathrm{N}$ isopropyl substituted dihydropyrazolone NPD-0227 (34, Table 2), which has a $\mathrm{pIC}_{50}$ of 6.4. Analogues containing larger alkyl groups on the $R_{2}$ position, such as cyclopropylmethyl 54, cyclobutylmethyl 55 , isopentyl 56, and cyclopentyl $\mathbf{5 7}$ all showed submicromolar antiparasitic activity (Table 2). Introduction of the larger cycloheptyl (58, Table 2) decreased the activity against $T$. cruzi while increasing the cytotoxicity. Introduction of a polar 2-hydroxyethyl group (59) on the pyrazolone nitrogen did not improve the activity compared to the unsubstituted dihydropyrazolone 51 (Table $2)$. Introducing butanenitrile $(60)$ or pentanenitrile $(61)$ led to improved activities compared to the unsubstituted pyrazolone 51 with $\mathrm{pIC}_{50}$ values of 5.4 and 5.9, respectively. To establish if aromatic moieties are allowed on the $R_{2}$ position, three methylpyridines (62-64, Table 2) were introduced. The observed activities were substantially higher than for the unsubstituted dihydropyrazolone (51). The 4-pyridinylmethyl $\left(64, \mathrm{pIC}_{50}=5.8\right)$ showed higher activity than the 2- and 3- pyridinylmethyl analogues $(62,63)$. However, the antiparasitic activity of the 4-pyridinylmethyl-substituted pyrazolone 64 $\left(\mathrm{pIC}_{50}=5.8\right)$ was well below the activity of the isopropyl derivative 34. Overall, variations on the $\mathrm{R}_{2}$-position did not improve the activity significantly compared to the isopropyl dihydropyrazolone (34, Table 2). Although the cyclopropylmethyl (54), cyclobutylmethyl (55), and cyclopentyl (57) dihydropyrazolones reached similar potencies as the isopropyl (34), the mild increase in toxicity observed with these compounds as well as higher clog $P$ values resulted in the decision to continue the SAR exploration on $\mathrm{R}_{3}$ (5, Figure 2) with the $N$-isopropyl moiety on the $\mathrm{R}_{2}$ position (34).

The final position that was varied on the phenylpyrazolone scaffold was the $R_{3}$ position (5, Figure 2). At first, small aliphatic moieties up to 5 carbons (75-79, Table 3) were introduced. While the smaller ethyl (75) and isopropyl (76) substituents showed a quite drastic drop in activity compared to the original methyl-substituted phenylpyrazolone (34) (Table 3), the slightly larger cyclopropylmethyl (77), cyclobutylmethyl (78), and cyclopentyl (79) are equipotent to the methoxy analogue (34) with $\mathrm{pIC}_{50}$ values around 6.3. Installing the larger benzyl group (80) caused a larger drop in activity $\left(\mathrm{pIC}_{50}\right.$ of 5.1).

In order to decrease the $\log P$, several aliphatic moieties with heteroatoms were installed. However, neither acetonitrile (81), tetrahydrofuran $(\mathbf{8 2})$, or tetrahydropyran $(83)$ moieties proved to provide a positive effect on activity (Table 3 ) as all these derivatives displayed a $\mathrm{pIC}_{50}$ of 5.0 or lower. Hence, the methoxy group, already present in the original hit, remains the substituent of choice.

After SAR-investigation on the three selected positions (5, Figure 2), the most optimal compound within these series contained a 3-pyridinyl moiety on $\mathrm{R}_{1}$, an isopropyl group on the $R_{2}$ position, and a methyl substituent on the $R_{3}$ position. The most active hit, the cyclopentyl-substituted phenyldihydropyrazolone (57, Table 2), was $\sim 32$ fold more active than the original hit (4, Figure 1). Nonetheless, it was decided to continue further studies with the 3-pyridinyl phenyldihydropyrazolone (34, NPD-0227) as it showed a slightly lower cytotoxicity ( $\sim 100$ fold selectivity) and generally had more favorable physicochemical properties compared to the 

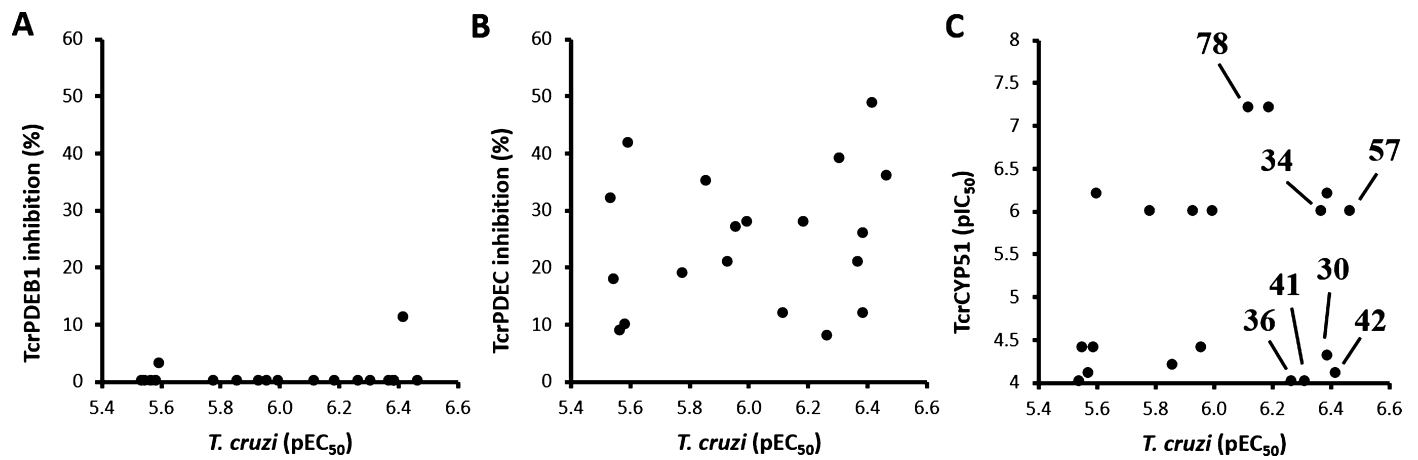

Figure 3. Measured biochemical evaluation activities of selected phenylpyrazolones correlate poorly with the phenotypic activity. (A) TcrPDEB1 inhibition at $10 \mu \mathrm{M}(\%)$ against the phenotypic inhibition on T. cruzi $\left(\mathrm{pIC}_{50}\right)$. (B) TcrPDEC inhibition at $10 \mu \mathrm{M}$ (\%) against the phenotypic inhibition on T. cruzi $\left(\mathrm{pIC}_{50}\right)$. (C) TcrCYP51 inhibition $\left(\mathrm{pIC}_{50}\right.$ ) against phenotypic inhibition on T. cruzi $\left(\mathrm{pIC}_{50}\right.$ ). Raw data can be found in Table S1.

Table 4. In Depth in Vitro Parasitology against BT of the Y-Strain (DTU II) and IC Amastigotes of the Tulahuen Strain (DTUs VI)

\begin{tabular}{|c|c|c|c|c|c|c|}
\hline cmpnd & $\mathrm{pIC}_{50}$ T. cruzi (Tulahuen, IC) $(96 \mathrm{~h})^{a}$ & $\mathrm{pIC}_{50}$ T. cruzi (Y-strain, BT) $(24 \mathrm{~h})^{a}$ & T. cruzi CYP51 (pIC50) ${ }^{a}$ & $\operatorname{clog} P^{b}$ & $\operatorname{clog} S^{b}$ & TPSA $(\AA)^{b}$ \\
\hline 3 & 5.6 & 4.9 & N.D. & 1.3 & -2.9 & 90 \\
\hline 30 & 6.2 & 4.3 & 4.3 & 4.5 & -5.9 & 66 \\
\hline 34 & 6.4 & $<4.3$ & 6.0 & 3.4 & -4.5 & 55 \\
\hline 36 & 6.3 & 4.3 & 4.0 & 4.0 & -5.5 & 55 \\
\hline 41 & 6.4 & 4.3 & 4.0 & 4.0 & -5.5 & 55 \\
\hline 42 & 6.2 & 4.3 & 4.1 & 3.6 & -4.7 & 55 \\
\hline 57 & 6.4 & 4.5 & 6.0 & 4.0 & -5.1 & 55 \\
\hline 78 & 6.0 & 3.9 & 7.2 & 4.7 & -6.0 & 55 \\
\hline
\end{tabular}

other equipotent analogues. The role of physicochemical properties was further investigated by plotting the T. cruzi pIC $_{50}$ 's against $\operatorname{cog} P, \operatorname{clog} S$, and TPSA. However, correlations were all poor with $\mathrm{R}^{2}$ 's below 0.15 (Table S1, Figures S1-S3).

\section{BIOCHEMICAL EVALUATION OF SELECTED PHENYLDIHYDROPYRAZOLONES}

As the hit originated from a PDE-focused library and was a moderately potent human PDE4 and TbrPDEB1 inhibitor, the possibility that these molecules exert their phenotypic effect via T. cruzi PDEs was explored. Additionally, compounds were screened for their activity against TcrCYP51 as the 3-pyridinyl moiety is a common chemotype for this known drug target. ${ }^{32}$

Analysis of PDE expression in T. cruzi based on the transcriptome data of $\mathrm{Li}$ et al. show that all five trypanosome PDEs (A, B1/B2, C, and D) are expressed in trypamastigotes, next to TcrCYP51. ${ }^{33}$ Expression levels of TcrPDEC and TcrCYP51 do not change more than two-fold after in vitro infection of human cells, while the mRNA concentrations of TcrPDEB1 and B2 were significantly (log 2 fold-change $>1 ; q$ value $<0.05)$ downregulated during the amastigote developmental stages (Supporting Information Figure S4). In epimastigotes (insect stage), only TcrPDEC was upregulated compared to trypomastigotes ( $\log 2$ fold-change $=2.7 ; q$-value $\left.=1.7 \times 10^{-10}\right)\left(\right.$ Figure S4). ${ }^{33}$

As mentioned, PDEB1 and PDEB2 of T. brucei have been shown to be essential for survival of the parasite. ${ }^{34}$ While not much is yet known about the role of the T. cruzi PDEB enzymes, its homology with the essential PDEB enzymes of $T$. brucei led to the hypothesis that TcrPDEB inhibition may be the underlying mechanism of the phenotypic activity of the phenyldihydropyrazolones. Therefore, the TcrPDEB1 catalytic domain was expressed and purified and selected molecules from the phenylpyrazolone series were evaluated for inhibitory potential of this enzyme in an in vitro activity assay (Figure $3 \mathrm{~A})$. Overall, the activity was very poor; for example, 3-methyl4-pyridinyl-substituted phenylpyrazolone $42\left(\mathrm{pIC}_{50} \mathrm{~T}\right.$. cruzi $=$ 6.4) inhibited $11 \%$ at $10 \mu \mathrm{M}$, while NPD-0227 (34, $\mathrm{pIC}_{50} T$. cruzi $=6.4$ ) did not show any TcrPDEB1 inhibition at all, making it unlikely that this enzyme is responsible for the observed phenotypic effect.

TcrPDEC was previously reported as a biochemically validated target by King-Keller et al.; hence, a selection of phenylpyrazolones was tested for their inhibition of the activity of the TcrPDEC catalytic domain (a.a. 270-614). ${ }^{29,31}$ Overall, the inhibitory activity of the phenyl-dihydropyrazolones against TcrPDEC-CD proved to be relatively weak (Figure 3B). The most potent phenotypic hits show less than 50\% inhibition of TcrPDEC-CD at $10 \mu \mathrm{M}$. For example, 3-methyl4-pyridinyl substituted phenylpyrazolone $\mathbf{4 2}$ inhibits $49 \%$ $\left(\mathrm{pIC}_{50}\right.$ T. cruzi $=6.4$, Table 1) and NPD-0227 (34) only $21 \%$ of TcrPDEC-CD activity $\left(\mathrm{pIC}_{50} \mathrm{~T}\right.$. cruzi $\left.=6.4\right)$. The poor correlation between the phenotypic activity and TcrPDEC-CD inhibition of this series suggests that this enzyme is also not a key mediator in the observed phenotypic effect (Figure 3B).

Inhibition of TcrCYP51 has previously been shown to lead to antiparasitic effects in vitro and in vivo. ${ }^{35-37}$ Yet, the recent posacanozole trial suggests that the azole-based TcrCYP51 inhibitor combined with benznidazole is not able to cure parasitemia. ${ }^{38}$ These findings have led to a serious debate on the validity of TcrCYP51 as drug target. ${ }^{37-44}$ However, in the posacanozole trial, the used dosage of the TcrCYP51 inhibitor only corresponds to $10-20 \%$ of the curative dose in mice. ${ }^{39,41}$ Moreover, the trial also employed a short treatment regimen, 
whereas it is also known that TcrCYP51 inhibitors are slow trypanocidal compounds. ${ }^{39,41,42}$ It has been suggested that with the design of specific TcrCYP51 inhibitors, instead of repurposing fungal CYP51 inhibitors, different combination therapies, or longer treatment regimens, TcrCYP51 inhibition still has potential. ${ }^{37,41,42,45}$ In order to investigate whether the observed antiparasitic effect of the newly identified hit series is caused by inhibition of TcrCYP51, a selection of inhibitors was screened against this enzyme. Gunatilleke et al. reported commonly observed scaffolds in the screening against TcrCYP51: amongst their top 185 ranked hits, 92 contained a 3-pyridinyl and 67 contained a 4-pyridinyl moiety, which is true for most compounds in the phenylpyrazolone series. ${ }^{32}$ Interestingly, two distinct groups are visible in Figure 3C while all compounds show phenotypic activity, one group showed $\mathrm{pIC}_{50}$ values $>6.0$ against CYP51, while the other group is virtually inactive. For example, NPD-0227 (34) inhibits TcrCYP51 with a $\mathrm{pIC}_{50}$ of $6.0\left(\mathrm{pIC}_{50}\right.$ T. cruzi = 6.4), while 4-fluoro-3-pyridinyl substituted phenylpyrazolone 36 (NPD0398; $\mathrm{pIC}_{50}$ T. cruzi $=6.3$ ) has a $\mathrm{pIC}_{50}$ of 4.0 on this enzyme (Figure 3C, Table 4). Also, compounds 30, 41, and 42 are similarly inactive against TcrCYP51, while still showing a submicromolar potency against T. cruzi.

\section{IN-DEPTH IN VITRO PARASITOLOGICAL EVALUATION}

Next, several of the most active phenylpyrazolones were tested more in-depth for their antiparasitic action. BT from the Ystrain (DTU II) and IC amastigotes of the Tulahuen, Y and Colombiana strains (DTUs VI, II, and I) were used. ${ }^{46}$ All compounds show (sub)micromolar activities against the amastigotes from the Tulahuen strain, but both TcrCYP51 actives (compounds $\mathbf{3 4}, \mathbf{5 7}, \mathbf{7 8}$, Figure $3 \mathrm{C}$, Table 4) as well as the inactives 30, 36 (NPD-0398), 41 and $\mathbf{4 2}$ (Figure 3C, Table 4) showed a similar drop in activity between the bloodstream form and the IC forms. Such a difference in phenotypic activity is observed more often and has been hypothesized to be an issue for TcrCYP51 inhibitors. ${ }^{36,47}$ Yet, in the current phenylpyrazolone series this difference in phenotypic activity is also seen for compounds without TcCYP51 inhibitory activity. Since all compounds have similar physicochemical properties (Table 4) and will thus have most likely similar cellular penetration, another unidentified mechanism of action is responsible for the observed phenotypic effects.

Screening of NPD-0227 (34) against the IC form of the nitro-drug-resistant strains, the $\mathrm{Y}$ and Colombiana showed $\mathrm{pIC}_{50}$ 's of 7.0 and 6.3, respectively (Table S3). Also, this compound did not present a cardiotoxic profile, leading to high selectivity indexes (SI) when amastigotes from the different strains were assessed inside cardiac cell cultures (Table S3).

\section{CONCLUSIONS}

By screening a PDE focused library for anti-T. cruzi compounds, phenyldihydropyrazolone 4 was identified as a starting point for further hit optimization. From this structure, the phenylpyrazolone scaffold (5, Figure 2) was derived and optimized at three different positions. Investigation of the $\mathrm{R}_{1}$ position led to the discovery of 3-pyridinyl-phenyldihydropyrazolone 34 (NPD-0227) as the best in this series, showing a $\mathrm{pIC}_{50}$ of 6.4 and 100 -fold selectivity over human MRC-5 cells and $>476$-fold selectivity over cardiac cell cultures. Although the $S A R$ investigation on the $R_{2}$ and $R_{3}$ positions ( 5 , Figure 2 ) yielded useful SAR data, activities did not improve compared to the initial hit. Screening of a selection of phenylpyrazolones on TcrPDEC and TcrPDEB1 showed low activities and poor correlation with phenotypic inhibition, suggesting that neither of these PDEs is responsible for the observed phenotypic activity. In vitro screening of phenylpyrazolones against TcrCYP51 showed both active and inactive compounds. Parasitic screening of both CYP51 actives (34, 57 and 78) and inactives $(30,36,41$ and 42$)$ indicates that inhibition of this enzyme is not responsible for the observed phenotypic action of this class of compounds. 3-Pyridine 34 (NPD-0227) shows improved phenotypic activity over the currently used drug benznidazole (1) on the IC form of the Tulahuen and Ystrain of $T$. cruzi $\left(\mathrm{pIC}_{50}=6.4\right.$ and 7.0 respectively) as well as against the highly nitro-drug-resistant Colombiana strain $\left(\mathrm{pIC}_{50}=6.3\right)$. The low activity of this series on the bloodstream form will likely prevent full sterile cure. Additional research is needed to improve the activity against the bloodstream form and/or evaluate this class of compounds for combination therapy against T. cruzi.

\section{EXPERIMENTAL SECTION BIOLOGY}

CYP51 Assay Protocol. Assay was carried out as described in Riley et al. ${ }^{30}$

T. cruzi Cellular Assay. BT of the Y strain of T. cruzi were obtained by cardiac puncture of infected Swiss Webster mice, on the parasitemia peak. ${ }^{48,49}$ For the standard in vitro susceptibility assay on IC amastigotes, T. cruzi Tulahuen CL2, $\beta$-galactosidase strain (nifurtimox-sensitive), was used. The strain is maintained on $\mathrm{MRC}-5_{\mathrm{SV} 2}$ (human lung fibroblast) cells7 in MEM medium, supplemented with $200 \mathrm{mM} \mathrm{L-}$ glutamine, $16.5 \mathrm{mM} \mathrm{NaHCO}_{3}$, and $5 \%$ inactivated fetal calf serum (FCSi). All cultures and assays are conducted at $37{ }^{\circ} \mathrm{C}$ under an atmosphere of $5 \% \mathrm{CO}_{2}$.

MRC-5 Cytotoxicity Cellular Assay. MRC-5 SV2 cells, originally from a human diploid lung cell line, were cultivated in MEM, supplemented with L-glutamine $(20 \mathrm{mM}), 16.5 \mathrm{mM}$ sodium hydrogen carbonate, and 5\% FCS. For the assay, $10^{4}$ cells/well were seeded onto the test plates containing the prediluted sample and incubated at $37{ }^{\circ} \mathrm{C}$ and $5 \% \mathrm{CO}_{2}$ for 72 $\mathrm{h}$. Cell viability was assessed fluorimetrically $4 \mathrm{~h}$ after addition of resazurin (excitation $550 \mathrm{~nm}$, emission $590 \mathrm{~nm}$ ). The results are expressed as percentage reduction in cell viability compared to untreated controls.

Cytotoxicity Assays on Cardiac Cells. Non-infected primary cardiac cell cultures were incubated at $37{ }^{\circ} \mathrm{C}$ for $48 \mathrm{~h}$ with increasing concentrations of each compound diluted in RPMI. Morphology and spontaneous contractibility were evaluated by light microscopy, and cellular viability was determined by PrestoBlue tests. ${ }^{50}$ The results are expressed as the difference in reduction between treated and nontreated cells according to the manufacturer instructions and the $\mathrm{LC}_{50}$ value (minimum concentration that reduces in 50\% the cellular viability) was determined. ${ }^{50}$

Trypanocidal Activity. BT from Y strain $\left(5 \times 10^{6} / \mathrm{mL}\right)$ obtained from the blood of Swiss male infected mice $\left(5 \times 10^{4}\right.$ par/animal, ip) at the parasitemia peak were incubated for $24 \mathrm{~h}$ at $37{ }^{\circ} \mathrm{C}$ in RPMI in the presence or absence of $1: 3$ serial dilutions of the compounds $(0-50 \mu \mathrm{M})$ for determination of parasite death rates through the direct quantification of live parasites by light microscopy. The $\mathrm{EC}_{50}$ (minimum compound concentration that reduces $50 \%$ of the number of parasites) was calculated. The more promising compounds $\left[\mathrm{EC}_{50} \leq\right.$ 
benznidazole (1)] were evaluated on IC amastigotes of the $\mathrm{Y}$ and Colombiana strains in infected cardiac cell cultures. ${ }^{48}$ After $24 \mathrm{~h}$ infection (10:1 parasite/cell rate), the cultures were treated for $48 \mathrm{~h}$ at $37{ }^{\circ} \mathrm{C}$ with nontoxic concentrations of the compounds. Following the treatment, the cultures were washed with saline, fixed with Bouin for $5 \mathrm{~min}$, stained with Giemsa, and evaluated by light microscopy. The percentage of infected host cells and the number of parasites per cell were determined for the calculation of the infection index, which represents the multiplication index using these two parameters, and then the $\mathrm{pIC}_{50}$ values were determined. ${ }^{49} \mathrm{SI}$ is expressed by the ratio between $\mathrm{pLC}_{50}$ (toxicity for mammalian cells) and the $\mathrm{pIC}_{50}$ (activity on the parasite).

Construction of Plasmids. The catalytic domains of Tcr(Y)PDEC (aa 270-614) and Tcr(Y)PDEB1 (aa 564-918) were amplified by PCR from full length sequences and cloned (NdeI and XhoI) into the vector pET28a. The sequences were verified by sequencing performed by GENEWIZ Inc.

Protein Production. Protein productions of both $\mathrm{Tcr}(\mathrm{Y})$ PDE_CDs were done following the same protocol. E. coli BL21(DE3)*pLysS was transformed with either plasmid pET28aTcr(Y)PDEC_270-614 or pET28aTcr(Y)PDEB1_564-918 and the resulting recombinant strains were grown in $2 \mathrm{YT}$ medium at $37{ }^{\circ} \mathrm{C}$. Protein overproduction overnight at $18{ }^{\circ} \mathrm{C}$ was induced with $0.5 \mathrm{mM}$ isopropyl 1-thio$\beta$-D-galactopyranoside (IPTG) at $\mathrm{OD}_{600}=0.6-0.8$. Harvested cells were resuspended in buffer A [20 mM Tris- $\mathrm{HCl}, \mathrm{pH} 8.0$, $500 \mathrm{mM} \mathrm{NaCl}, 20 \mathrm{mM}$ imidazole, $1 \mathrm{mM}$ dithiothreitol (DTT)] and lysed by one cycle of cell disruption at $25 \mathrm{kpsi}$.

Protein Purification. Protein purification was performed at $4{ }^{\circ} \mathrm{C}$. Cleared lysates were loaded on a $5 \mathrm{~mL}$ HisTrap HP column (GE Healthcare) charged with $\mathrm{NiSO}_{4}$. Unbound proteins were washed off with buffer $\mathrm{A}$ and the protein eluted with buffer A containing $400 \mathrm{mM}$ imidazole and immediately passed through a HiPrep 26/10 desalting column (GE Healthcare) equilibrated with $20 \mathrm{mM}$ Tris $\mathrm{HCl}, \mathrm{pH} 8.0,100$ $\mathrm{mM} \mathrm{NaCl}$, and $2 \mathrm{mM}$ DTT. Next, the protein was subjected overnight to Thrombin cleavage $(2-10$ units per $\mathrm{mg}$ of protein) at $4{ }^{\circ} \mathrm{C}$. Cleaved material was separated from uncleaved material by passing it through a gravity flow sepharose column charged with $\mathrm{NiSO}_{4}$ and further purified by ion-exchange chromatography on Q Sepharose (5 mL HiTrap Q HP, GE Healthcare) equilibrated in buffer C (50 mM Tris $\mathrm{HCl}, \mathrm{pH}$ 8.0, $100 \mathrm{mM} \mathrm{NaCl}, 1 \mathrm{mM} \mathrm{MgCl}$, and $1 \mathrm{mM} \mathrm{DTT}$ ). The protein was eluted with a linear gradient from 0 to $100 \%$ buffer D (50 mM Tris $\mathrm{HCl}, \mathrm{pH} 8.0,500 \mathrm{mM} \mathrm{NaCl}, 1 \mathrm{mM}$ $\mathrm{MgCl}_{2}$, and $1 \mathrm{mM} \mathrm{DTT}$ ) over 20 column volumes. Aggregates were removed by gel filtration on a Superdex 200 Increase 10/ $300 \mathrm{GL}$ (GE Healthcare) equilibrated in $20 \mathrm{mM}$ Tris $\mathrm{HCl}, \mathrm{pH}$ 7.5, $100 \mathrm{mM} \mathrm{NaCl}, 1 \mathrm{mM} \mathrm{MgCl} 2$, and $1 \mathrm{mM} \mathrm{DTT}$. A typical purification yielded about $10 \mathrm{mg}$ Tcr(Y)PDEC_CD and $7 \mathrm{mg}$ Tcr(Y)PDEB1_CDfrom a $1 \mathrm{~L}$ cell culture.

TcrPDEB1 and TcrPDEC Activity Assays. PDE activity assays were performed using the PDELight HTS cAMP phosphodiesterase kit (Lonza, Walkersville, USA). The assay is performed at $25{ }^{\circ} \mathrm{C}$ in nonbinding, low volume 384 wells plates (Corning, Kennebunk, ME, USA). PDE activity measurements (Tcr(Y)PDEC_CD; $K_{\mathrm{m}} 11.12 \mu \mathrm{M} \pm 1.78$, $\left.\mathrm{Tcr}(\mathrm{Y}) \mathrm{PDEB} 1 ; K_{\mathrm{m}} 2.22 \mu \mathrm{M} \pm 0,31\right)$ are made in "stimulation buffer" ( $50 \mathrm{mM}$ Hepes, $100 \mathrm{mM} \mathrm{NaCl}, 10 \mathrm{mM} \mathrm{MgCl}, 0.5 \mathrm{mM}$ EDTA, $0.05 \mathrm{mg} / \mathrm{mL}$ BSA, pH 7.5). For each PDE, the optimal enzyme concentration was determined according to the manufacturers protocol. Single concentration measurements are made at $10 \mu \mathrm{M}$ inhibitor concentration (Triplo measurements/assay, $n=2$ ). Dose-response curves were made in the range $100 \mu \mathrm{M}$ to $10 \mathrm{pM}$ (Triplo measurements/assay, $n=3$ ). Compounds were diluted in dimethyl sulfoxide (DMSO) (final concentration $1 \%)$. Inhibitor dilutions $(2,5 \mu \mathrm{L})$ were transferred to the 384-wells plate, 2, $5 \mu \mathrm{L}$ PDE in stimulation buffer is added and mixed, $5 \mu \mathrm{L}$ cAMP (at $2 \times K_{\mathrm{m}}$ up to $20 \mu \mathrm{M}$ ) is added, and the assay is incubated for $20 \mathrm{~min}$ at $300 \mathrm{rpm}$. The reaction is terminated by addition of $5 \mu \mathrm{L}$ Lonza Stop Buffer supplemented with $10 \mu \mathrm{M}$ NPD-0001. Next, $5 \mu \mathrm{L}$ of Lonza Detection reagent (diluted to $80 \%$ with reaction buffer) is added, and the reaction incubated for $10 \mathrm{~min}$, shaking 300 $\mathrm{rpm}$. Luminescence was read with a VICTOR3 luminometer using a $0.1 \mathrm{~s} /$ well program.

Relative light units (RLUs) were measured in comparison to the DMSO-only control; NPD-001 was taken along as positive control. The $K_{\mathrm{i}}$ values of the inhibitors are represented as the mean of at least three independent experiments with the associated standard error of the mean (SEM).

\section{EXPERIMENTAL SECTION CHEMISTRY}

Chemicals and reagents were obtained from commercial suppliers and were used without further purification. Anhydrous dimethylformamide (DMF), tetrahydrofuan (THF), and dichloromethane (DCM) were obtained by passing them through an activated alumina column prior to use. Microwave reactions were executed using a Biotage Initiator microwave system. ${ }^{1} \mathrm{H}$ NMR spectra were recorded on a Bruker AVANCE $250(250 \mathrm{MHz})$, Bruker AVANCE 400 (400 MHz), Bruker AVANCE $500(500 \mathrm{MHz})$, or Bruker 600 AVANCE $(600 \mathrm{MHz})$ spectrometer. Data are reported as follows: chemical shift, integration, multiplicity ( $\mathrm{s}=$ singlet, $\mathrm{d}=$ doublet, $\mathrm{dd}=$ double doublet, $\mathrm{t}=$ triplet, $\mathrm{dt}=$ double triplet, $\mathrm{q}$ $=$ quartet, $\mathrm{p}=$ pentet, $\mathrm{h}=$ heptet, $\mathrm{bs}=$ broad singlet, $\mathrm{m}=$ multiplet), and coupling constants $(\mathrm{Hz})$. Chemical shifts are reported in $\mathrm{ppm}$ with the natural abundance of deuterium in the solvent as the internal reference $\left(\mathrm{CDCl}_{3}: \delta\right.$ 7.26, $\left(\mathrm{CD}_{3}\right)_{2} \mathrm{SO}: \delta$ 2.50). ${ }^{13} \mathrm{C}$ NMR spectra were recorded on a Bruker AVANCE $500(126 \mathrm{MHz})$ or Bruker AVANCE 600 $(150 \mathrm{MHz})$. Chemical shifts are reported in ppm with the solvent resonance resulting from incomplete deuteration as the internal reference $\left(\mathrm{CDCl}_{3}: \delta 77.16\right.$ or $\left.\left(\mathrm{CD}_{3}\right)_{2} \mathrm{SO}: \delta 39.52\right)$. Systematic names for molecules according to IUPAC rules were generated using the Chemdraw AutoName program. Liquid chromatography-mass spectroscopy (LC-MS) data were gathered using a Shimadzu HPLC/MS workstation with an LC-20AD pump system, SPD-M20A diode array detector, and LCMS-2010 EV mass spectrometer. The column used is an XBridge $\mathrm{C} 185 \mu \mathrm{m}$ column $(100 \mathrm{~mm} \times 4.6 \mathrm{~mm})$. Solvents used were the following: solvent $\mathrm{B}=\mathrm{ACN}, 0.1 \%$ formic acid; solvent $\mathrm{A}=$ water, $0.1 \%$ formic acid. The analysis was conducted using a flow rate of $1.0 \mathrm{~mL} / \mathrm{min}$, start $5 \% \mathrm{~B}$, linear gradient to $90 \% \mathrm{~B}$ in $4.5 \mathrm{~min}$, and then $1.5 \mathrm{~min}$ at $90 \% \mathrm{~B}$, linear gradient to $5 \% \mathrm{~B}$ in $0.5 \mathrm{~min}$ and then $1.5 \mathrm{~min}$ at $5 \% \mathrm{~B}$, total run time of $8 \mathrm{~min}$. All reported compounds have purities $>95 \%$, measured at $254 \mathrm{~nm}$, unless otherwise mentioned. All highresolution mass spectroscopy (HRMS) spectra were recorded on a Bruker micrOTOF mass spectrometer using electron spray ionization (ESI) in positive-ion mode. Column purifications were either carried out automatically using Biotage equipment or manually, using 60-200 mesh silica. Thin-layer chromatography analyses were performed with Merck F254 alumina silica plates using UV visualization. All 
reactions were done under an $\mathrm{N}_{2}$ atmosphere, unless specifically mentioned.

General Methods. General Method A: Synthesis of $\beta$ Keto-esters. Benzoic acid 6 (25 g, $108 \mathrm{mmol})$ was suspended in DCM $(50 \mathrm{~mL})$ while cooling to $0{ }^{\circ} \mathrm{C}$. Subsequently, oxalyl dichloride $(13.7 \mathrm{~mL}, 162 \mathrm{mmol})$ and DMF (0.08 mL, 1.08 $\mathrm{mmol}$ ) were added and the mixture was allowed to warm up to room temperature. The mixture was stirred for $2 \mathrm{~h}$ after which volatiles were evaporated. The remaining solids were redissolved in $50 \mathrm{~mL}$ of THF. In a separate flask, methyl isobutyrate $(18.6 \mathrm{~mL}, 162 \mathrm{mmol})$ was stirred in THF $(50 \mathrm{~mL})$ at $-78{ }^{\circ} \mathrm{C}$ and a $2 \mathrm{M}$ lithium di-isopropyl amide (LDA) (65 $\mathrm{mL}, 130 \mathrm{mmol}$ ) was added dropwise while maintaining -78 ${ }^{\circ} \mathrm{C}$. Upon full addition, the mixture was stirred for $45 \mathrm{~min}$ after which the acid chloride of 6 in THF was added dropwise, again maintaining the temperature at $-78{ }^{\circ} \mathrm{C}$. The reaction was allowed to warm up to room temperature after which crude was quenched with water and extracted with diethyl ether. The organic phase was washed twice with water and once with brine. The organic layer was then dried with $\mathrm{MgSO}_{4}$, filtered, and evaporated to dryness. The crude was used in the next step without further purification.

General Method B: Ring Closure of $\beta$-Keto-esters. Crude keto-ester 7 ( $25 \mathrm{~g}, 79 \mathrm{mmol})$ was dissolved in ethanol $(75 \mathrm{~mL})$ and hydrazine hydrate $(64 \%)(38.6 \mathrm{~mL}, 793 \mathrm{mmol})$ was added. The reaction was stirred at room temperature for $48 \mathrm{~h}$ after which white precipitation was visible. To the stirred solution, $20 \mathrm{~mL}$ of water was added to allow further precipitation, after which solids were filtered off. Collected solids were dried in vacuo, yielding the desired product.

General Method C: N-Alkylation of Pyrazolones. Pyrazolone 8 (10 g, $34 \mathrm{mmol})$ was dissolved in dry DMF $(25 \mathrm{~mL})$ and cooled to $0{ }^{\circ} \mathrm{C}$. Sodium hydride (60\% in mineral oil) $(1.48$ g, $37 \mathrm{mmol}$ ) was added, and the reaction was stirred for $30 \mathrm{~min}$ at room temperature after which 2-bromopropane $(3.54 \mathrm{~mL}$, $38 \mathrm{mmol}$ ) was added. The reaction was stirred for $2 \mathrm{~h}$ at $50^{\circ} \mathrm{C}$ after which the reaction mixture was quenched with $50 \mathrm{~mL}$ of water. White solids precipitated after quenching, which were filtered off and washed with water $(2 \times 25 \mathrm{~mL})$. The white solids were dried in vacuo, yielding the target compound as a white solid. On a small scale $(<0.5 \mathrm{~g})$, not all analogues precipitated after quenching, instead a purification over $\mathrm{SiO}_{2}$ was done.

General Method D: Suzuki Coupling. Pyrazolone 11 (1.0 g, $3.0 \mathrm{mmol}$ ) and pyridin-3-ylboronic acid $(0.54 \mathrm{~g}, 4.4 \mathrm{mmol})$ were charged to a microwave vial after which dimethoxyethane (DME) $(12 \mathrm{~mL})$ and $1 \mathrm{M} \mathrm{Na}_{2} \mathrm{CO}_{3}(8.84 \mathrm{~mL}, 8.84 \mathrm{mmol})$ were added. The mixture was degassed with $\mathrm{N}_{2}$ for 5 min after which $\mathrm{Pd}(\mathrm{dppf}) \mathrm{Cl}_{2}(120 \mathrm{mg}, 0.15 \mathrm{mmol})$ was added. The reaction was then heated in the microwave for $1 \mathrm{~h}$ at $120^{\circ} \mathrm{C}$. The reaction mixture was diluted with $\mathrm{MTBE}$ and filtered over Celite. The residue was washed with saturated $\mathrm{NaHCO}_{3}(2 \times)$ and brine $(1 \times)$. The organic phase was dried over $\mathrm{Na}_{2} \mathrm{SO}_{4}$, filtered, and concentrated in vacuo to be further purified over $\mathrm{SiO}_{2}$ using a gradient of $40 \%$ EtOAc in heptane toward $60 \%$ EtOAc in heptane. The target compound was obtained as a white solid.

General Method E: Buchwald Coupling. Pyrazolone 11 (50 $\mathrm{mg}, 0.15 \mathrm{mmol})$, piperidine $(0.017 \mathrm{~mL}, 0.18 \mathrm{mmol}), \mathrm{Pd}_{2}(\mathrm{dba})_{3}$ (13 mg, $0.015 \mathrm{mmol})$, Xantphos (17 mg, $0.029 \mathrm{mmol})$, and $\mathrm{NatBuO}(28 \mathrm{mg}, 0.29 \mathrm{mmol})$ were added to a microwave tube. The mixture was diluted with dry toluene $(2 \mathrm{~mL})$ and degassed with $\mathrm{N}_{2}$ for $5 \mathrm{~min}$. The mixture was heated in the microwave at
$130{ }^{\circ} \mathrm{C}$ for $30 \mathrm{~min}$. The reaction mixture was diluted with MTBE and filtered over Celite. The residue was extracted with $1 \mathrm{M} \mathrm{Na}_{2} \mathrm{CO}_{3}(2 \times)$ and brine $(1 \times)$ after which the organic phase was dried over $\mathrm{Na}_{2} \mathrm{SO}_{4}$ and concentrated in vacuo. The remaining crude was purified over $\mathrm{SiO}_{2}$ using a gradient from $50 \%$ EtOAc in $n$-heptane toward $100 \%$ EtOAc, yielding the desired product as a white solid.

General Method F: Demethylation. Pyrazolone 11 (10 g, $29.5 \mathrm{mmol})$ was dissolved in dry DCM $(50 \mathrm{~mL})$ and mixture was cooled toward $-78{ }^{\circ} \mathrm{C}$. Subsequently, $1 \mathrm{M} \mathrm{BBr}_{3}$ in DCM $(59 \mathrm{~mL}, 59 \mathrm{mmol})$ was added dropwise over approximately 30 min. The dry-ice acetone bath was removed and the mixture allowed to warm toward room temperature and was stirred overnight. The reaction mixture was then quenched and diluted with water and extracted with MTBE. The organic phase was washed with brine $(1 \times)$ and dried over $\mathrm{MgSO}_{4}$. The crude was filtered after which remaining volatiles were evaporated in vacuo. The resulting crude was recrystallized from a DCM/MTBE mixture, yielding the product as a white solid.

General Method G: O-Alkylation of Demethylated Pyrazolones. Pyrazolone 65 (500 mg, $1.5 \mathrm{mmol}$ ) was dissolved in dry DMF $(5 \mathrm{~mL})$ and $\mathrm{Cs}_{2} \mathrm{CO}_{3}(1.0 \mathrm{~g}, 3.1$ $\mathrm{mmol}$ ) was added followed by (bromomethyl)cyclobutane $(0.19 \mathrm{~mL}, 1.7 \mathrm{mmol})$. The reaction mixture was stirred for $3 \mathrm{~h}$ at room temperature after which the mixture was poured in 30 $\mathrm{mL}$ of water. The aqueous phase was extracted with EtOAc after which the organic phase was washed twice with water followed by brine $(1 \times)$. The organic phase was dried over $\mathrm{MgSO}_{4}$, filtered, and evaporated to dryness. The resulting crude was purified over $\mathrm{SiO}_{2}$ using a gradient of $20 \%$ EtOAc in heptane toward 50\% EtOAc in heptane. Evaporation of pure fractions yielded the desired product as a white solid.

Below the experimental details of key-compounds 7, 8, 11, $34,65,67$, and 76 are included, which are representative for each reaction step. Details as well as the original spectra of all other compounds can be found in the Supporting Information.

Experimental Data. Methyl 3-(3-Bromo-4-methoxyphenyl)-2,2-dimethyl-3-oxopropanoate (7). Prepared according to general method A. Crude yield: $38 \mathrm{~g}$. Small portion was purified to obtain analysis data. ${ }^{1} \mathrm{H}$ NMR $\left(500 \mathrm{MHz}, \mathrm{CDCl}_{3}\right)$ : $\delta 8.11(\mathrm{~s}, 1 \mathrm{H}), 7.75(\mathrm{~d}, J=8.7 \mathrm{~Hz}, 1 \mathrm{H}), 6.88(\mathrm{~d}, J=8.7 \mathrm{~Hz}$, $1 \mathrm{H}), 3.95$ (s, 3H), 3.65 (s, 3H), $1.52(\mathrm{~s}, 6 \mathrm{H}) .{ }^{13} \mathrm{C}$ NMR $(126$ $\left.\mathrm{MHz}, \mathrm{CDCl}_{3}\right): \delta 194.9,175.5,159.2,134.4,129.6,128.8$, 112.1, 110.9, 56.5, 53.0, 52.7, 24.0. LC-MS (ESI) no mass observed; retention time: $4.84 \mathrm{~min}$.

5-(3-Bromo-4-methoxyphenyl)-4,4-dimethyl-2,4-dihydro$3 \mathrm{H}$-pyrazol-3-one (8). Prepared according to general method B starting from crude 7 to afford $22.2 \mathrm{~g}$ ( $75 \mathrm{mmol}$, 94\% over two steps) of the title compound as a white solid. ${ }^{1} \mathrm{H}$ NMR $\left(500 \mathrm{MHz}, \mathrm{DMSO}-d_{6}\right): \delta 11.54(\mathrm{~s}, 1 \mathrm{H}), 7.96(\mathrm{~d}, J=2.2 \mathrm{~Hz}$, $1 \mathrm{H}), 7.77(\mathrm{dd}, J=8.6,2.2 \mathrm{~Hz}, 1 \mathrm{H}), 7.16(\mathrm{~d}, J=8.7 \mathrm{~Hz}, 1 \mathrm{H})$, 3.89 (s, 3H), 1.34 (s, 6H). ${ }^{13} \mathrm{C}$ NMR (126 MHz, DMSO): $\delta$ $181.0,160.6,156.8,130.3,127.3,125.3,113.1,111.8,56.9$, 46.8, 22.3. LC-MS (ESI) $m / z$ : found, $297[\mathrm{M}+\mathrm{H}]^{+}$; retention time, $4.51 \mathrm{~min}$.

5-(3-Bromo-4-methoxyphenyl)-2-isopropyl-4,4-dimethyl2,4-dihydro-3H-pyrazol-3-one (11). Prepared according to general method $\mathrm{C}$ using 2-bromopropane $(0.95 \mathrm{~mL}, 10 \mathrm{mmol})$ to afford $2.0 \mathrm{~g}(5.9 \mathrm{mmol}, 70 \%)$ of the title compound as a white solid. ${ }^{1} \mathrm{H}$ NMR $\left(500 \mathrm{MHz}, \mathrm{CDCl}_{3}\right): \delta 8.06$ (d, $J=2.0$ $\mathrm{Hz}, 1 \mathrm{H}), 7.68$ (dd, $J=9.0 \mathrm{~Hz}, 2.0 \mathrm{~Hz}, 1 \mathrm{H}), 6.91(\mathrm{~d}, J=8.5 \mathrm{~Hz}$, $1 \mathrm{H}), 4.50$ (h, $J=6.5 \mathrm{~Hz}, 1 \mathrm{H}), 3.94(\mathrm{~s}, 3 \mathrm{H}), 1.44$ (s, 6H), 1.36 
$(\mathrm{d}, J=7.0 \mathrm{~Hz}, 6 \mathrm{H}) .{ }^{13} \mathrm{C} \mathrm{NMR}\left(126 \mathrm{MHz}, \mathrm{CDCl}_{3}\right): \delta 177.7$, 160.1, 156.9, 131.2, 126.5, 125.2, 112.3, 111.5, 56.4, 48.7, 45.3, 22.6, 20.8. LC-MS (ESI) $m / z$ : found, $339[\mathrm{M}+\mathrm{H}]^{+}$; retention time, $5.39 \mathrm{~min}$. HRMS-ESI: $[\mathrm{M}+\mathrm{H}]^{+}$calcd for $\mathrm{C}_{15} \mathrm{H}_{20} \mathrm{BrN}_{2} \mathrm{O}_{2}^{+}$, 339.0703; found, 339.0700.

2-Isopropyl-5-(4-methoxy-3-(pyridin-3-yl)phenyl)-4,4-dimethyl-2,4-dihydro-3H-pyrazol-3-one (34). Prepared according to general method D using pyridine-3-ylboronic acid (0.47 g, $3.8 \mathrm{mmol})$ to afford $650 \mathrm{mg}(1.93 \mathrm{mmol}, 65 \%)$ of the title compound as a white solid. ${ }^{1} \mathrm{H}$ NMR $\left(600 \mathrm{MHz} \mathrm{CDCl}_{3}\right): \delta$ 8.79 (s, 1H), $8.60(\mathrm{~s}, 1 \mathrm{H}), 7.90$ (d, $J=7.4 \mathrm{~Hz}, 1 \mathrm{H}), 7.83$ (d, $J$ $=2.2 \mathrm{~Hz}, 1 \mathrm{H}), 7.78(\mathrm{dd}, J=8.6,2.0 \mathrm{~Hz}, 1 \mathrm{H}), 7.39(\mathrm{~s}, 1 \mathrm{H})$, $7.03(\mathrm{~d}, J=8.7 \mathrm{~Hz}, 1 \mathrm{H}), 4.50$ (hept, $J=6.7 \mathrm{~Hz}, 1 \mathrm{H}), 3.87$ (s, $3 \mathrm{H}), 1.48$ (s, 6H), $1.36(\mathrm{~d}, J=6.7 \mathrm{~Hz}, 6 \mathrm{H}) .{ }^{13} \mathrm{C}$ NMR $(151$ $\left.\mathrm{MHz}, \mathrm{CDCl}_{3}\right): \delta 177.7,161.0,157.7,149.8,147.9,137.2$, 133.9, 128.7, 127.6, 127.5, 124.4, 123.2, 111.2, 55.8, 48.8, 45.3, 22.7, 20.8. LC-MS (ESI) $m / z$ : found, $338[\mathrm{M}+\mathrm{H}]^{+}$; retention time, $3.44 \mathrm{~min}$. HRMS-ESI $[\mathrm{M}+\mathrm{H}]^{+}$: calcd for $\mathrm{C}_{20} \mathrm{H}_{24} \mathrm{~N}_{3} \mathrm{O}_{2}^{+}$, 338.1863; found, 338.1851.

5-(3-Bromo-4-hydroxyphenyl)-2-isopropyl-4,4-dimethyl2,4-dihydro-3H-pyrazol-3-one (65). Prepared according to general method $\mathrm{F}$ using $1 \mathrm{M} \mathrm{BBr}_{3}$ in DCM to afford $8.2 \mathrm{~g}(25.2$ mmol, $86 \%)$ of the title compound as a white solid. ${ }^{1} \mathrm{H}$ NMR $\left(500 \mathrm{MHz}, \mathrm{CDCl}_{3}\right): \delta 7.97(\mathrm{~d}, J=2.0 \mathrm{~Hz}, 1 \mathrm{H}), 7.64(\mathrm{dd}, J=$ 8.6, $2.1 \mathrm{~Hz}, 1 \mathrm{H}), 7.06(\mathrm{~d}, J=8.6 \mathrm{~Hz}, 1 \mathrm{H}), 6.15(\mathrm{~s}, 1 \mathrm{H}), 4.50$ (hept, $J=6.7 \mathrm{~Hz}, 1 \mathrm{H}), 1.45(\mathrm{~s}, 6 \mathrm{H}), 1.36(\mathrm{~d}, J=6.7 \mathrm{~Hz}, 6 \mathrm{H})$. ${ }^{13} \mathrm{C}$ NMR $\left(126 \mathrm{MHz}, \mathrm{CDCl}_{3}\right): \delta 177.8,160.3,153.7,130.1$, $127.1,125.3,116.2,110.9,48.8,45.4,22.5,20.8$. LC-MS (ESI) $\mathrm{m} / z$ : found, $325[\mathrm{M}+\mathrm{H}]^{+}$; retention time, $4.87 \mathrm{~min}$. HRMS-ESI: $[\mathrm{M}+\mathrm{H}]^{+}$calcd for $\mathrm{C}_{14} \mathrm{H}_{18} \mathrm{BrN}_{2} \mathrm{O}_{2}{ }^{+}, 325.0546$; found, 325.0531 .

5-(3-Bromo-4-isopropoxyphenyl)-2-isopropyl-4,4-dimethyl-2,4-dihydro-3H-pyrazol-3-one (67). Prepared according to general method $\mathrm{G}$ using 2-bromopropane $(0.16 \mathrm{~mL}, 1.7$ $\mathrm{mmol})$ to afford $510 \mathrm{mg}(1.4 \mathrm{mmol}, 90 \%)$ of the title compound as a white solid. ${ }^{1} \mathrm{H} \mathrm{NMR}\left(500 \mathrm{MHz}, \mathrm{CDCl}_{3}\right): \delta$ $8.02(\mathrm{~d}, J=2.2 \mathrm{~Hz}, 1 \mathrm{H}), 7.64(\mathrm{dd}, J=8.6,2.2 \mathrm{~Hz}, 1 \mathrm{H}), 6.90$ $(\mathrm{d}, J=8.7 \mathrm{~Hz}, 1 \mathrm{H}), 4.60$ (hept, $J=6.0 \mathrm{~Hz}, 1 \mathrm{H}$ ), 4.48 (hept, $J=$ $6.7 \mathrm{~Hz}, 1 \mathrm{H}), 1.43(\mathrm{~s}, 6 \mathrm{H}), 1.39(\mathrm{~d}, J=6.1 \mathrm{~Hz}, 6 \mathrm{H}), 1.34$ (d, $J$ $=6.7 \mathrm{~Hz}, 6 \mathrm{H}) \cdot{ }^{13} \mathrm{C} \mathrm{NMR}\left(126 \mathrm{MHz}, \mathrm{CDCl}_{3}\right): \delta 177.7,160.2$, 155.6, 131.3, 126.2, 125.0, 114.6, 113.9, 72.1, 48.7, 45.2, 22.6, 22.0, 20.8. LC-MS (ESI) $m / z$ : found, $367[\mathrm{M}+\mathrm{H}]^{+}$; retention time, $5.54 \mathrm{~min}$. HRMS-ESI: $[\mathrm{M}+\mathrm{H}]^{+}$calcd for $\mathrm{C}_{17} \mathrm{H}_{24} \mathrm{BrN}_{2} \mathrm{O}_{2}$, 367.1016; found, 367.1012.

5-(4-Isopropoxy-3-(pyridin-3-yl)phenyl)-2-isopropyl-4,4dimethyl-2,4-dihydro-3H-pyrazol-3-one (76). Prepared according to general method D using pyridin-3-ylboronic acid $(87 \mathrm{mg}, 0.71 \mathrm{mmol})$ to afford $162 \mathrm{mg}(0.44 \mathrm{mmol}, 81 \%)$ of the title compound as a transparent oil which solidified over time. ${ }^{1} \mathrm{H} \mathrm{NMR}\left(500 \mathrm{MHz}, \mathrm{CDCl}_{3}\right.$ ): $\delta 8.81$ (broad singlet, $1 \mathrm{H}$ ), 8.58 $(\mathrm{d}, J=3.8 \mathrm{~Hz}, 1 \mathrm{H}), 7.88(\mathrm{~d}, J=7.9 \mathrm{~Hz}, 1 \mathrm{H}), 7.82(\mathrm{~d}, J=2.3$ $\mathrm{Hz}, 1 \mathrm{H}), 7.76(\mathrm{dd}, J=8.7,2.3 \mathrm{~Hz}, 1 \mathrm{H}), 7.36(\mathrm{dd}, J=7.8,4.8$ $\mathrm{Hz}, 1 \mathrm{H}), 7.02$ (d, $J=8.7 \mathrm{~Hz}, 1 \mathrm{H}), 4.62$ (hept, $J=6.0 \mathrm{~Hz}, 1 \mathrm{H}$ ), 4.51 (hept, $J=6.7 \mathrm{~Hz}, 1 \mathrm{H}), 1.48(\mathrm{~s}, 6 \mathrm{H}), 1.36(\mathrm{~d}, J=6.7 \mathrm{~Hz}$, $6 \mathrm{H}), 1.31$ (d, $J=6.1 \mathrm{~Hz}, 6 \mathrm{H}) \cdot{ }^{13} \mathrm{C}$ NMR $\left(126 \mathrm{MHz}, \mathrm{CDCl}_{3}\right)$ : $\delta 177.7,161.1,156.1,150.2,148.1,136.9,134.0,128.8,128.4$, 127.3, 124.0, 122.9, 113.7, 70.8, 48.8, 45.2, 22.7, 21.9, 20.8 . LC-MS (ESI) $m / z$ : found, $366[\mathrm{M}+\mathrm{H}]^{+}$; retention time, 3.92 min. HRMS-ESI: $[\mathrm{M}+\mathrm{H}]^{+}$calcd for $\mathrm{C}_{22} \mathrm{H}_{28} \mathrm{~N}_{3} \mathrm{O}_{2}$, 366.2176; found, 366.2185 .

\section{ASSOCIATED CONTENT}

\section{Supporting Information}

The Supporting Information is available free of charge on the ACS Publications website at DOI: 10.1021/acsomega.8b02847.

Detailed pharmacological and parasitological data as well as tables of physical chemical properties of synthesized compounds; correlation between physical chemical properties with parasite growth inhibition; detailed experimental data for the compounds 9-10, 12-33, 35-64, 66, 68-74, 75 and 77-83; and NMR data files of all compounds (PDF)

\section{AUTHOR INFORMATION}

\section{Corresponding Author}

*E-mail: r.leurs@vu.nl (R.L.).

ORCID $\odot$

Rob Leurs: 0000-0003-1354-2848

\section{Author Contributions}

Performing experimental work: Maarten Sijm, K.M.O., J.S.d.A., S.S., A.M., T.v.d.M., P.S., H.C., and I.C.; writing manuscript: M.S., M.d.N.C.S, R.L.; experimental design: M.S., E.E., Marco Siderius, L.M., D.G.B., J.J.M., M.d.N.C.S, G.S., I.J.P.d.E., and R.L.; funding: L.M., D.G.B., M.d.N.C.S, G.S., I.J.P.d.E., and R.L.; reviewing and editing manuscript: M.S., M.d.N.C.S, G.S., and R.L. All authors have given approval to the final version of the manuscript.

Funding

The PDE4NPD project was funded by the European Union under the FP-7-Health program, project ID: 602666. MNCS is a researcher with the $\mathrm{CNPq}$ and CNE/FAPERJ.

Notes

The authors declare no competing financial interest.

\section{ACKNOWLEDGMENTS}

The authors would like to thank all other members of PDE4NPD for insightful discussions and helpful comments. Furthermore, we thank Stijn Laan, Krishnili Ramratan, Amid Sangar, Eakta Singh, and Ruth Willems for their assistance on the synthesis.

\section{LIST OF ABBREVIATIONS}

a.a., amino acid; bs, broad singlet, BT: bloodstream trypomastigotes; cAMP, cyclic adenosine monophosphate; $\mathrm{CD}$, catalytic domain; cGMP, cyclic guanosine monophosphate; $\operatorname{clog} P$, calculated logarithm of the partitioncoefficient; CYP51, cytochorome P450 51; d, doublet; DCM, dichloromethane; dd, double doublet; DME, dimethoxyethane; dt, double triplet; DTU, discrete typing units; DMF, dimethylformamide; dppf, 1,1'-ferrocenediyl-bis(diphenylphosphine); DTT, dithiothreitol; EDTA, ethylenediaminetetraacetic acid; ESI, electron spray ionization; EtOAc, ethylacetate; FCS, fetal calf serum; FPMK, fragments per kilobase of transcript per million mapped reads; q, quartet; h, heptet; HRMS, high-resolution mass spectroscopy; HTS, high-throughput screening; Hz, hertz; J, coupling constant; IC, intracellular; LC-MS, liquid chromatography-mass spectroscopy; LDA, lithium di-isopropyl amide; m, multiplet; $\mathrm{MeOH}$, methanol; MHz, megahertz; MRC-5, medical research council cell strain 5; mRNA, messenger RNA; MTBE, methyl tertbutyl ether; NMR, nuclear magnetic resonance; p, pentet; 
PDE, phosphodiesterase; q, quartet; RLU, relative light unit; s, singlet; SAR, structure-activity relationship; SEM, standard error of the mean; $t$, triplet; Tbr, Trypanosoma brucei; Tcr, Trypanosoma cruzi; THF, tetrahydrofuan; TPSA, topical polar surface area

\section{REFERENCES}

(1) Schmunis, G. Trypanosoma cruzi, the etiologic agent of Chagas' disease: status in the blood supply in endemic and nonendemic countries. Transfusion 1991, 31, 547-557.

(2) Bern, C.; Montgomery, S. P. An Estimate of the Burden of Chagas Disease in the United States. Clin. Infect. Dis. 2009, 49, e52e54.

(3) Bern, C.; Kjos, S.; Yabsley, M. J.; Montgomery, S. P. Trypanosoma cruzi and Chagas' Disease in the United States. Clin. Microbiol. Rev. 2011, 24, 655-681.

(4) Coura, J. R.; Viñas, P. A. Chagas disease: a new worldwide challenge. Nature 2010, 465, S6-S7.

(5) Schmunis, G. A.; Yadon, Z. E. Chagas disease: A Latin American health problem becoming a world health problem. Acta Trop. 2010, $115,14-21$.

(6) http://www.dndi.org/diseases-projects/diseases/chagas.html (Dec 12, 2015).

(7) WHO. Chagas disease (American trypanosomiasis). http:// www.who.int/mediacentre/factsheets/fs340/en/ (Nov 05, 2018).

(8) Urbina, J. A.; Docampo, R. Specific chemotherapy of Chagas disease: controversies and advances. Trends Parasitol. 2003, 19, 495501.

(9) Morillo, C. A.; Marin-Neto, J. A.; Avezum, A.; Sosa-Estani, S.; Rassi, A.; Rosas, F.; Villena, E.; Quiroz, R.; Bonilla, R.; Britto, C.; Guhl, F.; Velazquez, E.; Bonilla, L.; Meeks, B.; Rao-Melacini, P.; Pogue, J.; Mattos, A.; Lazdins, J.; Rassi, A.; Connolly, S. J.; Yusuf, S. Randomized Trial of Benznidazole for Chronic Chagas' Cardiomyopathy. N. Engl. J. Med. 2015, 373, 1295-1306.

(10) Castro, J. A.; deMecca, M. M.; Bartel, L. C. Toxic Side Effects of Drugs Used to Treat Chagas' Disease (American Trypanosomiasis). Hum. Exp. Toxicol. 2006, 25, 471-479.

(11) Zingales, B.; Araujo, R. G. A.; Moreno, M.; Franco, J.; Aguiar, P. H. N.; Nunes, S. L.; Silva, M. N.; Ienne, S.; Machado, C. R.; Brandão, A. A novel ABCG-like transporter of Trypanosoma cruzi is involved in natural resistance to benznidazole. Memórias do Inst. Oswaldo Cruz 2015, 110, 433-444.

(12) Rogers, N. Bugging out over Chagas: Bioluminescent protozoans and old drugs might help unravel kissing-bug disease. Nat. Med. 2015, 21, 1108-1110.

(13) Cerecetto, H.; González, M. Synthetic Medicinal Chemistry in Chagas' Disease: Compounds at The Final Stage of "Hit-To-Lead" Phase. Pharmaceuticals 2010, 3, 810-838.

(14) Khare, S.; Nagle, A. S.; Biggart, A.; Lai, Y. H.; Liang, F.; Davis, L. C.; Barnes, S. W.; Mathison, C. J. N.; Myburgh, E.; Gao, M.-Y.; Gillespie, J. R.; Liu, X.; Tan, J. L.; Stinson, M.; Rivera, I. C.; Ballard, J.; Yeh, V.; Groessl, T.; Federe, G.; Koh, H. X. Y.; Venable, J. D.; Bursulaya, B.; Shapiro, M.; Mishra, P. K.; Spraggon, G.; Brock, A.; Mottram, J. C.; Buckner, F. S.; Rao, S. P. S.; Wen, B. G.; Walker, J. R.; Tuntland, T.; Molteni, V.; Glynne, R. J.; Supek, F. Proteasome inhibition for treatment of leishmaniasis, Chagas disease and sleeping sickness. Nature 2016, 537, 229-233.

(15) Peña, I.; Pilar Manzano, M.; Cantizani, J.; Kessler, A.; AlonsoPadilla, J.; Bardera, A. I.; Alvarez, E.; Colmenarejo, G.; Cotillo, I.; Roquero, I.; de Dios-Anton, F.; Barroso, V.; Rodriguez, A.; Gray, D. W.; Navarro, M.; Kumar, V.; Sherstnev, A.; Drewry, D. H.; Brown, J. R.; Fiandor, J. M.; Julio Martin, J. New Compound Sets Identified from High Throughput Phenotypic Screening Against Three Kinetoplastid Parasites: An Open Resource. Sci. Rep. 2015, 5, 8771.

(16) Keravis, T.; Lugnier, C. Cyclic nucleotide phosphodiesterase (PDE) isozymes as targets of the intracellular signalling network: benefits of PDE inhibitors in various diseases and perspectives for future therapeutic developments. Br. J. Pharmacol. 2012, 165, 12881305.

(17) Maurice, D. H.; Ke, H.; Ahmad, F.; Wang, Y.; Chung, J.; Manganiello, V. C. Advances in targeting cyclic nucleotide phosphodiesterases. Nat. Rev. Drug Discov. 2014, 13, 290-314.

(18) Mancini, P.; Patton, C. Cyclic 3',5'-adenosine monophosphate levels during the developmental cycle of Trypanosoma brucei brucei in the rat. Mol. Biochem. Parasitol. 1981, 3, 19-31.

(19) Rangel-Aldao, R.; Allende, O.; Triana, F.; Piras, R.; Henriquez, D.; Piras, M. Possible role of cAMP in the differentiation of Trypanosoma cruzi. Mol. Biochem. Parasitol. 1987, 22, 39-43.

(20) Kunz, S.; Beavo, J. A.; D’Angelo, M. A.; Flawia, M. M.; Francis, S. H.; Johner, A.; Laxman, S.; Oberholzer, M.; Rascon, A.; Shakur, Y.; Wentzinger, L.; Zoraghi, R.; Seebeck, T. Cyclic nucleotide specific phosphodiesterases of the kinetoplastida: A unified nomenclature. Mol. Biochem. Parasitol. 2006, 145, 133-135.

(21) Orrling, K. M.; Jansen, C.; Vu, X. L.; Balmer, V.; Bregy, P.; Shanmugham, A.; England, P.; Bailey, D.; Cos, P.; Maes, L.; Adams, E.; van den Bogaart, E.; Chatelain, E.; Ioset, J.-R.; van de Stolpe, A.; Zorg, S.; Veerman, J.; Seebeck, T.; Sterk, G. J.; de Esch, I. J. P.; Leurs, R. Catechol Pyrazolinones as Trypanocidals: Fragment-Based Design, Synthesis, and Pharmacological Evaluation of Nanomolar Inhibitors of Trypanosomal Phosphodiesterase B1. J. Med. Chem. 2012, 55, $8745-8756$.

(22) Jansen, C.; Wang, H.; Kooistra, A. J.; de Graaf, C.; Orrling, K. M.; Tenor, H.; Seebeck, T.; Bailey, D.; de Esch, I. J. P.; Ke, H.; Leurs, R. Discovery of Novel Trypanosoma brucei Phosphodiesterase B1 Inhibitors by Virtual Screening against the Unliganded TbrPDEB1 Crystal Structure. J. Med. Chem. 2013, 56, 2087-2096.

(23) Kunz, S.; Balmer, V.; Sterk, G. J.; Pollastri, M. P.; Leurs, R.; Müller, N.; Hemphill, A.; Spycher, C. The single cyclic nucleotidespecific phosphodiesterase of the intestinal parasite Giardia lamblia represents a potential drug target. PLoS Neglected Trop. Dis. 2017, 11, e0005891.

(24) de Koning, H. P.; Gould, M. K.; Sterk, G. J.; Tenor, H.; Kunz, S.; Luginbuehl, E.; Seebeck, T. Pharmacological Validation of Trypanosoma brucei Phosphodiesterases as Novel Drug Targets. J. Infect. Dis. 2012, 206, 229-237.

(25) Veerman, J.; van den Bergh, T.; Orrling, K. M.; Jansen, C.; Cos, P.; Maes, L.; Chatelain, E.; Ioset, J.-R.; Edink, E. E.; Tenor, H.; Seebeck, T.; de Esch, I.; Leurs, R.; Sterk, G. J. Synthesis and evaluation of analogs of the phenylpyridazinone NPD-001 as potent trypanosomal TbrPDEB1 phosphodiesterase inhibitors and in vitro trypanocidals. Bioorg. Med. Chem. 2016, 24, 1573-1581.

(26) Makin, L.; Gluenz, E. cAMP signalling in trypanosomatids: role in pathogenesis and as a drug target. Trends Parasitol. 2015, 31, 373379.

(27) Rohloff, P.; Montalvetti, A.; Docampo, R. Acidocalcisomes and the Contractile Vacuole Complex Are Involved in Osmoregulation inTrypanosoma cruzi. J. Biol. Chem. 2004, 279, 52270-52281.

(28) Rohloff, P.; Rodrigues, C. O.; Docampo, R. Regulatory volume decrease in Trypanosoma cruzi involves amino acid efflux and changes in intracellular calcium. Mol. Biochem. Parasitol. 2003, 126, 219-230.

(29) King-Keller, S.; Li, M.; Smith, A.; Zheng, S.; Kaur, G.; Yang, X.; Wang, B.; Docampo, R. Chemical Validation of Phosphodiesterase C as a Chemotherapeutic Target in Trypanosoma cruzi, the Etiological Agent of Chagas' Disease. Antimicrob. Agents Chemother. 2010, 54, $3738-3745$.

(30) Riley, J.; Brand, S.; Voice, M.; Caballero, I.; Calvo, D.; Read, K. D. Development of a Fluorescence-based Trypanosoma cruzi CYP51 Inhibition Assay for Effective Compound Triaging in Drug Discovery Programmes for Chagas Disease. PLoS Neglected Trop. Dis. 2015, 9, e0004014.

(31) Wang, H.; Kunz, S.; Chen, G.; Seebeck, T.; Wan, Y.; Robinson, H.; Martinelli, S.; Ke, H. Biological and Structural Characterization of Trypanosoma cruziPhosphodiesterase $\mathrm{C}$ and Implications for Design of Parasite Selective Inhibitors. J. Biol. Chem. 2012, 287, 11788-11797. 
(32) Gunatilleke, S. S.; Calvet, C. M.; Johnston, J. B.; Chen, C.-K.; Erenburg, G.; Gut, J.; Engel, J. C.; Ang, K. K. H.; Mulvaney, J.; Chen, S.; Arkin, M. R.; McKerrow, J. H.; Podust, L. M. Diverse Inhibitor Chemotypes Targeting Trypanosoma cruzi CYP51. PLoS Neglected Trop. Dis. 2012, 6, e1736.

(33) Li, Y.; Shah-Simpson, S.; Okrah, K.; Belew, A. T.; Choi, J.; Caradonna, K. L.; Padmanabhan, P.; Ndegwa, D. M.; Temanni, M. R.; Corrada Bravo, H.; El-Sayed, N. M.; Burleigh, B. A. Transcriptome Remodeling in Trypanosoma cruzi and Human Cells during Intracellular Infection. PLoS Pathog. 2016, 12, e1005511.

(34) Tagoe, D. N. A.; Kalejaiye, T. D.; de Koning, H. P. The ever unfolding story of cAMP signaling in trypanosomatids: vive la difference! Front. Pharmacol. 2015, 6, 185.

(35) Andriani, G.; Amata, E.; Beatty, J.; Clements, Z.; Coffey, B. J.; Courtemanche, G.; Devine, W.; Erath, J.; Juda, C. E.; Wawrzak, Z.; Wood, J. T.; Lepesheva, G. I.; Rodriguez, A.; Pollastri, M. P. Antitrypanosomal Lead Discovery: Identification of a Ligand-Efficient Inhibitor of Trypanosoma cruzi CYP51 and Parasite Growth. J. Med. Chem. 2013, 56, 2556-2567.

(36) Lepesheva, G. I.; Hargrove, T. Y.; Anderson, S.; Kleshchenko, Y.; Furtak, V.; Wawrzak, Z.; Villalta, F.; Waterman, M. R. Structural Insights into Inhibition of Sterol $14 \alpha$-Demethylase in the Human PathogenTrypanosoma cruzi. J. Biol. Chem. 2010, 285, 25582-25590.

(37) Soeiro, M. d. N. C.; de Souza, E. M.; da Silva, C. F.; Batista, D. d. G. J.; Batista, M. M.; Pavão, B. P.; Araújo, J. S.; Aiub, C. A. F.; da Silva, P. B.; Lionel, J.; Britto, C.; Kim, K.; Sulikowski, G.; Hargrove, T. Y.; Waterman, M. R.; Lepesheva, G. I. In VitroandIn VivoStudies of the Antiparasitic Activity of Sterol 14 $\alpha$-Demethylase (CYP51) Inhibitor VNI against Drug-Resistant Strains of Trypanosoma cruzi. Antimicrob. Agents Chemother. 2013, 57, 4151-4163.

(38) Molina, I.; Gómez i Prat, J.; Salvador, F.; Treviño, B.; Sulleiro, E.; Serre, N.; Pou, D.; Roure, S.; Cabezos, J.; Valerio, L.; Blanco-Grau, A.; Sánchez-Montalvá, A.; Vidal, X.; Pahissa, A. Randomized Trial of Posaconazole and Benznidazole for Chronic Chagas' Disease. N. Engl. J. Med. 2014, 370, 1899-1908.

(39) Saccoliti, F.; Madia, V. N.; Tudino, V.; De Leo, A.; Pescatori, L.; Messore, A.; De Vita, D.; Scipione, L.; Brun, R.; Kaiser, M.; Mäser, P.; Calvet, C. M.; Jennings, G. K.; Podust, L. M.; Pepe, G.; Cirilli, R.; Faggi, C.; Di Marco, A.; Battista, M. R.; Summa, V.; Costi, R.; Di Santo, R. Design, Synthesis, and Biological Evaluation of New 1(Aryl-1H-pyrrolyl)(phenyl)methyl-1H-imidazole Derivatives as Antiprotozoal Agents. J. Med. Chem. 2019, 62, 1330-1347.

(40) Villalta, F.; Dobish, M. C.; Nde, P. N.; Kleshchenko, Y. Y.; Hargrove, T. Y.; Johnson, C. A.; Waterman, M. R.; Johnston, J. N.; Lepesheva, G. I. VNI Cures Acute and Chronic Experimental Chagas Disease. J. Infect. Dis. 2013, 208, 504-511.

(41) Molina, I.; Salvador, F.; Sánchez-Montalvá, A. The use of posaconazole against Chagas disease. Curr. Opin. Infect. Dis. 2015, 28, 397-407.

(42) Lepesheva, G. I.; Friggeri, L.; Waterman, M. R. CYP51 as drug targets for fungi and protozoan parasites: past, present and future. Parasitology 2018, 145, 1820-1836.

(43) Guedes-da-Silva, F. H.; Batista, D. G. J.; Da Silva, C. F.; De Araújo, J. S.; Pavão, B. P.; Simões-Silva, M. R.; Batista, M. M.; Demarque, K. C.; Moreira, O. C.; Britto, C.; Lepesheva, G. I.; Soeiro, M. N. C. Antitrypanosomal Activity of Sterol $14 \alpha$-Demethylase (CYP51) Inhibitors VNI and VFV in the Swiss Mouse Models of Chagas Disease Induced by the Trypanosoma cruzi Y Strain. Antimicrob. Agents Chemother. 2017, 61, e02098-16.

(44) Chatelain, E.; Ioset, J.-R. Phenotypic screening approaches for Chagas disease drug discovery. Expert Opin. Drug Discov. 2018, 13, 141-153.

(45) Lepesheva, G. I.; Hargrove, T. Y.; Rachakonda, G.; Wawrzak, Z.; Pomel, S.; Cojean, S.; Nde, P. N.; Nes, W. D.; Locuson, C. W.; Calcutt, M. W.; Waterman, M. R.; Daniels, J. S.; Loiseau, P. M.; Villalta, F. VFV as a New Effective CYP51 Structure-Derived Drug Candidate for Chagas Disease and Visceral Leishmaniasis. J. Infect. Dis. 2015, 212, 1439-1448.
(46) Higuera, S. L.; Guhl, F.; Ramírez, J. Identification of Trypanosoma cruzi Discrete Typing Units (DTUs) through the implementation of a High-Resolution Melting (HRM) genotyping assay. Parasites Vectors 2013, 6, 112.

(47) Hargrove, T. Y.; Wawrzak, Z.; Alexander, P. W.; Chaplin, J. H.; Keenan, M.; Charman, S. A.; Perez, C. J.; Waterman, M. R.; Chatelain, E.; Lepesheva, G. I. Complexes of Trypanosoma cruziSterol $14 \alpha$-Demethylase (CYP51) with Two Pyridine-based Drug Candidates for Chagas Disease. J. Biol. Chem. 2013, 288, 31602-31615.

(48) Meirelles, M. N.; de Araujo-Jorge, T. C.; Miranda, C. F.; de Souza, W.; Barbosa, H. S. Interaction of Trypanosoma cruzi with heart muscle cells: ultrastructural and cytochemical analysis of endocytic vacuole formation and effect upon myogenesis in vitro. Eur. J. Cell Biol. 1986, 41, 198.

(49) Batista, D. d. G. J.; Batista, M. M.; Oliveira, G. M. d.; Amaral, P. B. d.; Lannes-Vieira, J.; Britto, C. C.; Junqueira, A.; Lima, M. M.; Romanha, A. J.; Sales Junior, P. A.; Stephens, C. E.; Boykin, D. W.; Soeiro, M. d. N. C. Arylimidamide DB766, a Potential Chemotherapeutic Candidate for Chagas' Disease Treatment. Antimicrob. Agents Chemother. 2010, 54, 2940-2952.

(50) Timm, B. L.; da Silva, P. B.; Batista, M. M.; da Silva, F. H. G.; da Silva, C. F.; Tidwell, R. R.; Patrick, D. A.; Jones, S. K.; Bakunov, S. A.; Bakunova, S. M.; Soeiro, M. d. N. C. In VitroandIn VivoBiological Effects of Novel Arylimidamide Derivatives against Trypanosoma cruzi. Antimicrob. Agents Chemother. 2014, 58, 3720-3726. 